\title{
Adaptation and validation of social accountability measures in the context of contraceptive services in Ghana and Tanzania
}

Victoria Boydell ${ }^{1 *}$ (D, Petrus S. Steyn ${ }^{2}$, Joanna Paula Cordero ${ }^{2}$, Ndema Habib ${ }^{2}$, My Huong Nguyen², Dela Nai ${ }^{3}$ and Donat Shamba ${ }^{4}$

\begin{abstract}
Background: Changes in the values, attitudes, and interactions of both service users and health care providers are central to social accountability processes in reproductive health. However, there is little consensus on how best to measure these latent changes. This paper reports on the adaptation and validation of measures that capture these changes in Tanzania and Ghana.

Methods: The CaPSAl theory of change determined the dimensions of the measure, and we adapted existing items for the survey items. Trained data collectors used a survey to collect data from 752 women in Tanzania and 750 women in Ghana attending contraceptive services. We used reliability analysis, exploratory, and confirmatory factor analysis to assess the validity and reliability of these measures in each country.

Results: The measure has high construct validity and reliability in both countries. We identified several subscales in both countries, 10 subscales in Tanzania, and 11 subscales in Ghana. Many of the domains and items were shared across both settings.

Conclusion: The study suggests that the multi-dimensional scales have high construct validity and reliability in both countries. Though there were differences in the two country contexts and in items and scales, there was convergence in the analysis that suggests that this measure may be relevant in different settings and should be validated in new settings.
\end{abstract}

Trial registration: ACTRN12619000378123.

Keywords: Social accountability, Measurement, Contraception, Tanzania, Ghana

\section{Background}

Considerable progress has been made in increasing women's access to modern contraception [35]. Nevertheless, there is continuing unmet need, particularly for those with less education, lower incomes, and younger age, and high rates of discontinuation due to poor

\footnotetext{
* Correspondence: vickyboydell@gmail.com

${ }^{1}$ Global Health Institute, Geneva Graduate Institute, Geneva, Switzerland

Full list of author information is available at the end of the article
}

quality of care and negative patient experience $[10,35$, 39]. In recent years, there have been renewed efforts to understand better and address issues surrounding the quality of care and clients' experiences of contraceptive services. Studies have identified a range of quality care issues that negatively affect clients' experiences of interacting with contraceptive services $[3,17,25]$.

Community engagement and more patient-centred care have come to the forefront as essential mechanisms 
to address issues around quality of care and poor client experience $[24,40]$. Evidence increasingly indicates the positive effects of social accountability on improving the quality of care and experience in other health sectors and concerning contraception specifically $[5,13,38]$. We define social accountability as "citizens' efforts at ongoing meaningful collective engagement with public institutions for accountability in the provision of public goods." ([18], pg 161). It is often best recognized through the tools used to facilitate the process, such as community scorecards, social audits, and participatory budget. As a potentially transformative change process, social accountability transforms the norms, values, and attitudes of those seeking services and those providing them, which together can bring about changes in the health system delivery and, in the longer term, population health outcomes. However, the all-important changes in service users and providers' norms, values, and attitudes are often not measured, possibly because they are not observable but rather latent and multi-dimensional.

Though few validated measures aim to capture these variables, a notable exception is CARE's Women's Voice tool that provides an important starting point for researchers in this area [34]. As part of a more extensive complex intervention study [36], we adapted and validated measures of service users' attitudes and behaviors in a social accountability process to improve family planning services. In this paper, we describe the process of adapting the measures and assessing their validity and reliability in Ghana and Tanzania.

\section{Methods}

The larger study's theory of change about how service users' attitudes changed during the social accountability process determined the dimensions of the measures. To develop the survey items, we adapted existing items. Trained data collectors used a survey to collect data from women attending contraceptive services in Tanzania and Ghana. We used reliability analysis, exploratory, and confirmatory factor analysis to assess the validity and reliability of these measures in each country.

The development of these measures is part of a more extensive complex intervention study, Community and Provider Social Accountability Intervention (CaPSAI), undertaken in Tanzania and Ghana [36]. These countries were selected based on the following criteria: (1) existence of a national civil society organization (CSO) partner with experience in social accountability, (2) low modern contraceptive prevalence rate, (3) availability of contraceptive services at the point of contact where cost is not a barrier to access, (4) an enabling environment in terms of the potential for the health system to respond to the social accountability, and (5) the existence of formal structures linking the community with the health system (e.g. health committees).

The study took place in Mbeya City and Chunya districts in Tanzania, and Abura-Asebu-Kwamankese, Komenda-Edna-Eguafo-Abirem, and Mfantsiman districts in Ghana. The sites were selected based on (1) the provision of contraceptive services; (2) availability of the following methods: a barrier method, a short and long-acting method, emergency contraception, and at least referral for permanent methods in districts; and (3) no social accountability interventions in FP/C currently underway [36] Table 1 .

\section{Dimensions of the measure}

The theory of change drew on existing empirical and theoretical work on social accountability more broadly and specifically related to sexual and reproductive health (see $[7,8,36])$. This informed the dimensions in the measure. The theory of change, Fig. 1, details the inputs of the social accountability process (across the top of the diagram), how these correspond to the cumulative intermediate outcomes at three levels: (1) service users, (2) social networks and (3) service providers, which in turn, effect intended reforms in the quality of care that contribute to contraceptive choice, including increased uptake and use of modern contraceptive methods. As detailed in elsewhere, social accountability engages community members and health services actors in dialogues to identify shared challenges and develop action plans that can lead to improvements in service quality in the health system and in at the individual level, the service user or potential user knowledge and engagement with the health system, both in terms of their own health seeking behaviour and their participation in dialogues with authorities [36].

\section{Item adaptation and development}

Following the development of the dimensions, we identified existing validated measures for each domain. We drew heavily on CARE's Women VOICES tool, a validated measure the aimed to capture similar intermediate outcomes concerning maternal health in Malawi [34]. We added three domains to those used in the VOICES tool to represent the CaPSAI theory of change fully. First was the 'Knowledge and awareness of rights' domain that aimed to capture the service user's perception of rights were also included [42]. For service users' efficacy with health care providers, we used the National Health Service (NHS) measure of patient activation [28]. To capture changes in service user's awareness of how to bring about changes and improve their local services, we created items based on theoretical work on political capabilities [22, 41]. We adapted five VOICES validated scales with acceptable reliability to the contraceptive 


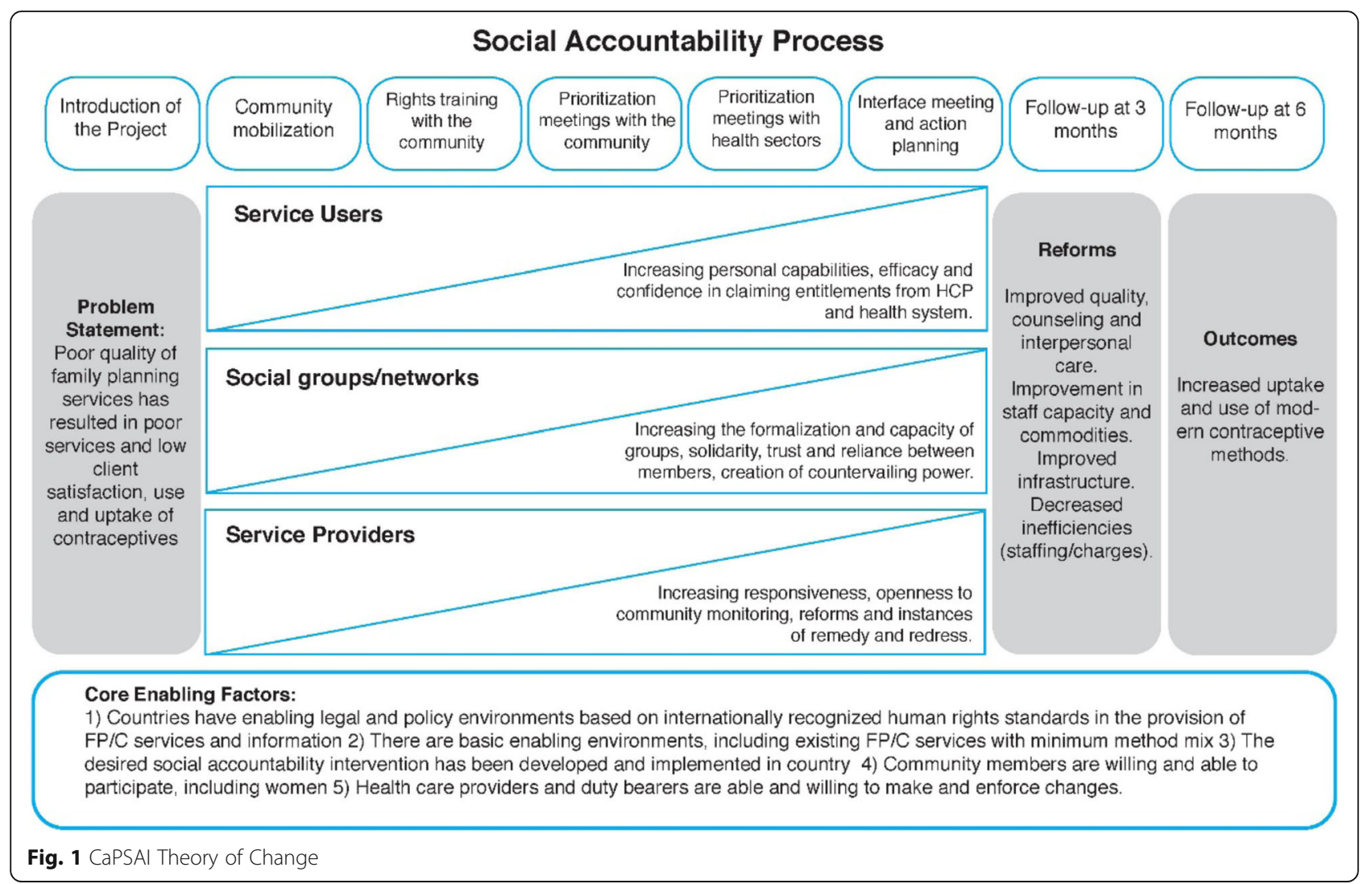

services and local context; for example, family planning services have a charge in Ghana but not in Tanzania. A total of 14 domains were included with 75 items (see Tables 2 and 3). A five-point Likert scale was used for all the item with the exception of two sets of items had different ranges in their original format. A 6 point scale was used for Self-efficacy with health care providers (set A) 'Women's participation in household decision- making' and a dichotomous scale was used for 'Self-efficacy with health care providers (set A)' as originally used [28, 34].

We ascertained content validity of the overall items through consultation with experts in social accountability and family planning, and the Principal Investigators who reviewed the questionnaire. Also, the World Health Organization (WHO) Forms Committee, which was

Table 1 Characteristics of the study settings [36]

\begin{tabular}{lll}
\hline Type of facilities & Ghana $(\boldsymbol{n}=\mathbf{8})$ & Tanzania $(\boldsymbol{n}=\mathbf{8})$ \\
\hline District Hospital & 1 & 0 \\
Health Centre /Clinic & 6 & 2 \\
Health Post (Community-based & 1 & Not Applicable \\
Health Planning Services - Ghana) & & \\
Dispensary (Tanzania) & Not Applicable & 6 \\
\hline
\end{tabular}

Table 2 Domains identified based on Theory of Change

\begin{tabular}{|c|c|}
\hline Domains & $\begin{array}{l}\text { Number of } \\
\text { Items }\end{array}$ \\
\hline Knowledge and awareness of rights ${ }^{c}$ & $8^{\mathrm{b}}$ \\
\hline Women's participation in household decision- making ${ }^{a}$ & $10^{\mathrm{b}}$ \\
\hline Self-efficacy with health care providers ${ }^{c}$ & $13^{\mathrm{b}}$ \\
\hline Self-efficacy for participation at community meetings ${ }^{a}$ & $6^{b}$ \\
\hline Perception of service quality ${ }^{a}$ & $6^{\mathrm{b}}$ \\
\hline Political capabilities ${ }^{c}$ & $5^{\mathrm{b}}$ \\
\hline Collective efficacy ${ }^{a}$ & $4^{b}$ \\
\hline Community support in time of crisis $^{\text {a }}$ & $4^{b}$ \\
\hline Mutual responsibility for and support of services ${ }^{a}$ & $5^{\mathrm{b}}$ \\
\hline Participation in negotiated spaces ${ }^{a}$ & 4 \\
\hline Joint monitoring and accountability of services ${ }^{a}$ & 2 \\
\hline Transparency ${ }^{a}$ & 3 \\
\hline Equity of negotiated spaces ${ }^{a}$ & 3 \\
\hline Quality of negotiated spaces ${ }^{\text {a }}$ & 3 \\
\hline
\end{tabular}

avalidated from CARE's Women VOICES Tool

${ }^{b}$ scales tested in this study

'new scales 
Table 3 List of items included, per domain

Komain
rights

Women's participation in household decision- making

Self-efficacy with health care providers A

Self-efficacy with health care providers $B$

Self-efficacy for participation at community meetings

\section{Likert No. Item}

Range

1-5 38 A healthcare provider can refuse to provide me family planning services because of who I am.

39 The government ensures that family planning services are free of cost (Tanzania) or The government ensures that family planning methods are free of cost (Ghana)

40 I have the right to privacy during my family planning visit. ${ }^{a}$

41 The healthcare provider should not share my information with other people.

42 If I am unhappy with the care I received, I know there are ways to make a complaint. ${ }^{\text {a }}$

43 Healthcare providers must answer all my health-related questions. ${ }^{a}$

44 Healthcare providers should inform me about the different family planning options ${ }^{a}$

45 I can refuse any family planning method offered if I do not want to use it. ${ }^{\text {a }}$

1-6 46 First, would you tell me which member of your household usually makes decisions about your health care? ${ }^{\text {a }}$

47 Which member of your household usually makes decisions about making large household purchases? ${ }^{\mathrm{a}}$

48 Which member of your household usually makes decisions about making household purchases for daily needs? ${ }^{\text {? }}$

49 Which member of your household usually makes decisions about when you will visit family/ relatives/friends? ? $^{\mathrm{n}}$

50 Which member of your household usually makes decisions about when your whole household will visit family/relatives/friends?

51 Which member of your household usually makes decisions about how to use the money that you bring into the household?

52 Which member of your household usually makes decisions about how to use the money your husband/partner brings into the household? ${ }^{a}$

53 Which member of your household usually makes decisions about whether you or you and your husband/partner use family planning? ${ }^{a}$

54 Which member of your household usually makes decisions about where you will receive family planning?

55 Which member of your household usually makes decisions about if you will be tested for the AIDS virus? ${ }^{a}$

56 Which member of your household usually makes decisions about how many children you will have? ${ }^{\text {a }}$

1-2 57 After your consultation with the health care provider today, do you know what your reproductive and family planning options are? ${ }^{a}$

58 After your consultation with the health care provider today, do you feel that you can act on your choice for family planning? ${ }^{\text {a }}$

59 Do you know what help you need to make a decision? ${ }^{2}$

1-5 65 I felt like I could discuss my problems, question and concerns with the health care provider without feeling embarrassed.

66 One of the providers or staff refused to offer me the service I wanted to receive. (reverse(coded) $)^{a}$

67 The provider ignored my request or my preferences today. ${ }^{a}$

68 I felt like the provider did not listen to what I was saying (reverse-coded) ${ }^{\mathrm{a}}$

69 A provider strongly encouraged me to use one family planning that was different to the one I wanted (reverse-coded) ${ }^{a}$

70 I have the right to choose my family planning method.

1-5 71 How sure are you that you could attend a community meeting if your family did not support you to participate? ${ }^{\mathrm{a}}$

72 How sure are you that you could attend a community meeting if your family said you could not go? ${ }^{\text {a }}$

73 How sure are you that you could attend a community meeting if your family would not help with your household duties so that you could attend? ${ }^{a}$ 
Table 3 List of items included, per domain (Continued)

\begin{tabular}{|c|c|c|c|}
\hline Domain & $\begin{array}{l}\text { Likert } \\
\text { Range }\end{array}$ & No. & Item \\
\hline & & 74 & How sure are you that you could express your opinion at a community meeting? ${ }^{a}$ \\
\hline & & 75 & $\begin{array}{l}\text { How sure are you that you could express your opinion at a community meeting if a few people } \\
\text { did not agree with what you were saying? }\end{array}$ \\
\hline & & 76 & $\begin{array}{l}\text { How sure are you that you could express your opinion at a community meeting if many people } \\
\text { did not agree with what you were saying? }{ }^{\text {a }}\end{array}$ \\
\hline \multirow[t]{6}{*}{ Perception of service quality } & $1-5$ & 77 & The staff at this health facility have high quality family planning services ${ }^{\text {a }}$ \\
\hline & & 78 & The staff at this health facility ensures privacy and confidentiality when providing services. ${ }^{a}$ \\
\hline & & 79 & The health facility is clean. ${ }^{a}$ \\
\hline & & 80 & $\begin{array}{l}\text { At this health facility, if women choose, they can bring their husband/partner for the family } \\
\text { planning consultation. }{ }^{\text {a }}\end{array}$ \\
\hline & & 81 & $\begin{array}{l}\text { At this health facility, if women choose, they can bring a family member or friend for the family } \\
\text { planning consultation. }{ }^{\text {a }}\end{array}$ \\
\hline & & 82 & $\begin{array}{l}\text { Unmarried women can access family planning and reproductive health service at the health } \\
\text { facility. }\end{array}$ \\
\hline \multirow[t]{5}{*}{ Political capabilities } & $1-5$ & 83 & $\begin{array}{l}\text { Today, if I went to the clinic, I believe I could get family planning I wanted without facing any } \\
\text { barriers of cost, age and marital status. }\end{array}$ \\
\hline & & 84 & $\begin{array}{l}\text { Anyone outside of the clinic, like friends or community members, can help you access your right } \\
\text { to quality family planning services. }\end{array}$ \\
\hline & & 85 & $\begin{array}{l}\text { Health providers and district government officials can directly influence the quality of your local } \\
\text { family planning services? }\end{array}$ \\
\hline & & 86 & $\begin{array}{l}\text { Challenging people of influence is the best way to change family planning services in the clinic. } \\
\text { a }\end{array}$ \\
\hline & & 87 & $\begin{array}{l}\text { Collaboration with people of influence is the best way to change family planning services in the } \\
\text { clinic. }{ }^{\text {a }}\end{array}$ \\
\hline \multirow[t]{4}{*}{ Collective efficacy } & $1-5$ & 88 & $\begin{array}{l}\text { How sure are you that the people in your community could work together to improve family } \\
\text { planning services in this community? }\end{array}$ \\
\hline & & 89 & $\begin{array}{l}\text { How sure are you that the people in your community could work together to improve how } \\
\text { women are treated at the health facility? }\end{array}$ \\
\hline & & 90 & $\begin{array}{l}\text { How sure are you that the people in your community could work together to obtain } \\
\text { government services and entitlements? }\end{array}$ \\
\hline & & 91 & $\begin{array}{l}\text { How sure are you that the people in your community could work together to improve the } \\
\text { health and well- being of women in this community? }\end{array}$ \\
\hline \multirow[t]{4}{*}{$\begin{array}{l}\text { Community support in time of } \\
\text { crisis }\end{array}$} & $1-5$ & 92 & $\begin{array}{l}\text { How sure are you that there is someone in your community, apart from your immediate family, } \\
\text { who you could go to for advice? }{ }^{\text {a }}\end{array}$ \\
\hline & & 93 & $\begin{array}{l}\text { How sure are you that there is someone in your community, apart from your immediate family, } \\
\text { who could take you to the clinic? }\end{array}$ \\
\hline & & 94 & $\begin{array}{l}\text { How sure are you that there is someone in your community, apart from your immediate family, } \\
\text { who would help care for your children or household while you are away? }{ }^{\text {a }}\end{array}$ \\
\hline & & 95 & $\begin{array}{l}\text { How sure are you that there is someone in your community, apart from your immediate family, } \\
\text { who would loan you money for transport? }\end{array}$ \\
\hline \multirow[t]{5}{*}{$\begin{array}{l}\text { Mutual responsibility for and } \\
\text { support of services }\end{array}$} & $1-5$ & 99 & $\begin{array}{l}\text { Who could have the most impact on making sure that women are treated with respect by } \\
\text { health workers? }\end{array}$ \\
\hline & & 100 & $\begin{array}{l}\text { Who could have the most impact on making sure that women have transportation to the } \\
\text { hospital for permanent methods of contraception? }{ }^{\text {a }}\end{array}$ \\
\hline & & 101 & $\begin{array}{l}\text { Who could have the most impact on increasing the number of days a health worker visits your } \\
\text { community? }\end{array}$ \\
\hline & & 102 & $\begin{array}{l}\text { Who could have the most impact on making sure the poorest and most vulnerable women in } \\
\text { the community receive care? }{ }^{\mathrm{a}}\end{array}$ \\
\hline & & 103 & $\begin{array}{l}\text { Who could have the most impact on getting funding to improve health services in this } \\
\text { community? }\end{array}$ \\
\hline
\end{tabular}


composed of technical experts in contraception, social scientists, biostatisticians, and data managers, reviewed the instruments.

\section{Survey administration}

English surveys were available in both countries and translated in Akan in Ghana and into Kiswahili in Tanzania. Back translation was within a normal range, and pretesting the questionnaire was satisfactory for use in the study populations.
The same eligibility criteria for participants were used in both sites (see [36]). A sample of over 750 women aged 15 to 49 years accessing contraceptive services was interviewed prior to the start of the intervention in each country. Sampling was calculated using a priori sample size calculation with the ratio of 10 responses per item ratio and guidance of more than 500, which equals a very good sample for validation [4, 34]. Our sample calculation was based on 75 items of the full survey of items, including post test items. The same items were administered as part of a client exit interview survey in

Table 4 Demographic Characteristics of Ghana and Tanzania Sample

\begin{tabular}{|c|c|c|}
\hline & Ghana n (\%) & Tanzania n (\%) \\
\hline \multicolumn{3}{|l|}{ Age, years } \\
\hline Mean (SD) [Min, Max] & $28.4(7.1)[15,49]$ & $27.8(6.3)[16 ., 47]$ \\
\hline Median (IR) & $27(23,33)$ & $27(23,32)$ \\
\hline$\leq 20$ & $94(12.5)$ & $83(11.1)$ \\
\hline $20-39$ & $636(70.1)$ & $567(75.6)$ \\
\hline$>39$ & $130(17.4)$ & $100(13.3)$ \\
\hline \multicolumn{3}{|l|}{ Marital status } \\
\hline Currently married & $476(63.5)$ & $636(84.8)$ \\
\hline Never married & $225(30.0)$ & $77(10.3)$ \\
\hline Other (Cohabitation, Fiance, no husband, separated, divorced) & $49(6.5)$ & $37(4.9)$ \\
\hline \multicolumn{3}{|l|}{ Methods currently using (among those using) } \\
\hline Female sterilization & $7(1.1 \%)$ & $11(1.5 \%)$ \\
\hline Male sterilization & $2(0.3)$ & $3(0.4)$ \\
\hline IUD & $8(1.3)$ & $40(5.5)$ \\
\hline Injectables & $456(71.7)$ & $391(53.7)$ \\
\hline Implants & $128(20.1)$ & $217(29.8)$ \\
\hline Pill & $32(5.0)$ & $122(16.8)$ \\
\hline Male condom & $17(2.7)$ & $53(7.3)$ \\
\hline Female condom & $5(0.8)$ & $9(1.2)$ \\
\hline Emergency contraception & $11(1.7)$ & $1(0.1)$ \\
\hline Standard days method & $7(1.1)$ & $24(3.3)$ \\
\hline Lactational amenorrhea method & $6(0.9)$ & $27(3.7)$ \\
\hline Other (Rhythm method/ withdrawal) & $22(3.4)$ & $73(10.1)$ \\
\hline \multicolumn{3}{|l|}{ Highest level of school completed } \\
\hline No formal schooling & $131(17.5)$ & $29(3.9)$ \\
\hline Some primary school & $243(32.4)$ & $48(6.4)$ \\
\hline Completed primary school & $194(25.9)$ & $423(56.4)$ \\
\hline Some secondary school (some and completed) & $109(14.5)$ & $222(29.6)$ \\
\hline Any tertiary education & $73(9.7)$ & $28(3.7)$ \\
\hline \multicolumn{3}{|l|}{ Reading level } \\
\hline Cannot read at all & $303(40.4)$ & $34(4.5)$ \\
\hline Able to read only part of the sentence & $187(24.9)$ & $105(14.0)$ \\
\hline Able to read whole sentence & $259(34.5)$ & $611(81.5)$ \\
\hline
\end{tabular}


Table 5 Reliability Analysis in Tanzania

\begin{tabular}{|c|c|c|c|c|c|}
\hline Qn \# & $\begin{array}{l}\text { Scale } \\
\text { mean if } \\
\text { item } \\
\text { deleted }\end{array}$ & $\begin{array}{l}\text { Scale } \\
\text { Standard } \\
\text { Deviation }\end{array}$ & Variance & $\begin{array}{l}\text { Item total } \\
\text { Correlation } \\
\text { with Total }\end{array}$ & $\begin{array}{l}\text { Alpha } \\
\text { if item } \\
\text { deleted }\end{array}$ \\
\hline
\end{tabular}

Knowledge and Awareness of Rights

$\begin{array}{llllll}38^{*} & 2.71 & 1.42 & 2.01 & -0.17 & \mathbf{0 . 8 3} \\ 39 & 1.46 & 0.61 & 0.37 & 0.55 & 0.72 \\ 40 & 1.61 & 0.65 & 0.42 & 0.58 & 0.71 \\ 41 & 1.63 & 0.70 & 0.49 & 0.55 & 0.72 \\ 42 & 2.24 & 1.26 & 1.58 & 0.47 & 0.73 \\ 43 & 1.64 & 0.60 & 0.36 & 0.62 & 0.70 \\ 44 & 1.62 & 0.59 & 0.34 & 0.67 & 0.69 \\ 45 & 1.78 & 1.02 & 1.04 & 0.49 & 0.73 \\ \text { Reliability Coeffcients } & \text { Alpha }= & & \text { N of cases } & \text { N of } \\ & & 0.83 & & 752 & \text { items: 7 }\end{array}$

Women's participation in household decision-making (all items)

$\begin{array}{llllll}46+ & 1.60 & 0.49 & 0.24 & 0.51 & \mathbf{0 . 8 8} \\ 47+ & 1.41 & 0.49 & 0.24 & 0.48 & 0.88 \\ 48 \dagger & 1.69 & 0.46 & 0.21 & 0.56 & 0.88 \\ 49+ & 1.64 & 0.48 & 0.23 & 0.66 & 0.87 \\ 50 \dagger & 1.62 & 0.48 & 0.23 & 0.65 & 0.87 \\ 51 \dagger & 1.72 & 0.45 & 0.20 & 0.67 & 0.87 \\ 52 \dagger & 1.63 & 0.48 & 0.23 & 0.51 & 0.88 \\ 53 \dagger & 1.81 & 0.39 & 0.15 & 0.68 & 0.87 \\ 54 \dagger & 1.84 & 0.36 & 0.13 & 0.69 & 0.87 \\ 55 \dagger & 1.82 & 0.38 & 0.15 & 0.62 & 0.87 \\ 56 \dagger & 1.76 & 0.43 & 0.18 & 0.56 & 0.88 \\ \text { Reliability Coeffcients } & \text { Alpha }= & & \text { N of cases } & \text { N of } \\ & & 0.83 & & 752 & \text { items: }\end{array}$

Self efficacy with health care providers (Qn 57, 58 \& 59)

\begin{tabular}{|c|c|c|c|c|c|}
\hline $57^{* *}$ & 0.94 & 0.23 & 0.05 & 0.43 & 0.43 \\
\hline $58^{* *}$ & 0.95 & 0.22 & 0.05 & 0.51 & 0.31 \\
\hline $59^{* *}$ & 0.76 & 0.43 & 0.18 & 0.26 & 0.68 \\
\hline $\begin{array}{l}\text { liabi } \\
\text { effci }\end{array}$ & & $\begin{array}{l}\text { Alph } \\
0.59\end{array}$ & & $\begin{array}{l}N \text { of cases } \\
752\end{array}$ & $\begin{array}{l}\mathrm{N} \text { of } \\
\text { items: } 2\end{array}$ \\
\hline
\end{tabular}

Self efficacy with health care providers (all items)

$\begin{array}{cccccc}65 & 2.67 & 1.38 & 1.89 & -0.16 & \mathbf{0 . 7 4} \\ 66^{*} & 1.95 & 0.90 & 0.81 & 0.55 & 0.46 \\ 67^{*} & 1.82 & 0.81 & 0.66 & 0.58 & 0.45 \\ 68^{*} & 1.89 & 0.86 & 0.74 & 0.53 & 0.47 \\ 69^{*} & 2.03 & 1.02 & 1.04 & 0.48 & 0.50 \\ 70 & 1.55 & 0.73 & 0.54 & 0.18 & \mathbf{0 . 6 2} \\ \text { Reliability Coeffcients } & \text { Alpha }= & & \text { N of cases } & \text { N of } \\ & & 0.81 & & 752 & \text { items: } 3\end{array}$

Self-efficacy for participation at community meetings (all items) (Qn 7173)
71
1.88
1.27
1.61
0.73
0.75

Table 5 Reliability Analysis in Tanzania (Continued)

\begin{tabular}{cclcll}
\hline Qn \# & $\begin{array}{l}\text { Scale } \\
\text { mean if } \\
\text { item } \\
\text { deleted }\end{array}$ & $\begin{array}{l}\text { Scale } \\
\text { Standard } \\
\text { Deviation }\end{array}$ & Variance & $\begin{array}{l}\text { Item total } \\
\text { Correlation } \\
\text { with Total }\end{array}$ & $\begin{array}{l}\text { Alpha } \\
\text { if item } \\
\text { deleted }\end{array}$ \\
\hline 72 & 2.05 & 1.31 & 1.72 & 0.80 & 0.69 \\
73 & 2.06 & 1.26 & 1.59 & 0.60 & $\mathbf{0 . 8 8}$ \\
Reliability Coeffcients & $\begin{array}{l}\text { Alpha } \\
0.88\end{array}$ & & $\begin{array}{l}\text { N of cases } \\
752\end{array}$ & $\begin{array}{l}\mathrm{N} \text { of } \\
\text { items:2 }\end{array}$
\end{tabular}

Self-efficacy for participation at community meetings (all items)

$\begin{array}{llllll}74 & 2.02 & 1.30 & 1.69 & 0.65 & 0.93 \\ 75 & 2.49 & 1.42 & 2.02 & 0.85 & 0.76 \\ 76 & 2.63 & 1.49 & 2.22 & 0.81 & 0.78 \\ \text { Reliability Coeffcients } & \text { Alpha }= & & \text { N of cases } & \text { N of } \\ & & 0.88 & & 752 & \text { items: 2 }\end{array}$

Perception of service quality (all items)

$\begin{array}{llllll}77 & 1.62 & 0.64 & 0.41 & 0.58 & 0.64 \\ 78 & 1.59 & 0.59 & 0.35 & 0.59 & 0.64 \\ 79 & 1.70 & 0.65 & 0.42 & 0.53 & 0.66 \\ 80 & 1.70 & 0.73 & 0.53 & 0.49 & 0.67 \\ 81 & 2.26 & 1.08 & 1.17 & 0.35 & 0.71 \\ 82 & 2.18 & 1.11 & 1.23 & 0.21 & \mathbf{0 . 7 5} \\ \text { Reliability Coeffcients } & \text { Alpha }= & & \text { N of cases } & \text { N of } \\ & & 0.75 & & 752 & \text { items: } 5\end{array}$

Political Capabilities

$\begin{array}{llllll}83 & 1.99 & 1.10 & 1.21 & 0.06 & \mathbf{0 . 7 9} \\ 84 & 2.60 & 1.25 & 1.57 & 0.44 & \mathbf{0 . 6 5} \\ 85 & 1.93 & 0.85 & 0.72 & 0.52 & 0.61 \\ 86 & 2.10 & 1.03 & 1.06 & 0.66 & 0.55 \\ 87 & 2.09 & 1.03 & 1.05 & 0.65 & 0.55 \\ \text { Reliability Coeffcients } & \text { Alpha }= & & \text { N of cases } & \text { N of } \\ & & 0.81 & & 752 & \text { items:4 }\end{array}$

\section{Collective efficacy (all items)}

\begin{tabular}{|c|c|c|c|}
\hline 1.91 & 1.23 & 1.51 & 0.67 \\
\hline 1.91 & 1.13 & 1.28 & 0.79 \\
\hline 1.80 & 1.06 & 1.12 & 0.71 \\
\hline 1.86 & 1.10 & 1.21 & 0.70 \\
\hline bility Coeffcients & $\begin{array}{l}\text { Alpha }= \\
0.87\end{array}$ & & $\begin{array}{l}\mathrm{N} \text { of cases } \\
0751\end{array}$ \\
\hline
\end{tabular}

Community support in time of crisis (all items)

$\begin{array}{llllll}92 & 1.72 & 1.27 & 1.61 & 0.39 & 0.57 \\ 93 & 1.70 & 1.13 & 1.28 & 0.49 & 0.50 \\ 94 & 1.90 & 1.28 & 1.64 & 0.39 & 0.57 \\ 95 & 2.11 & 1.38 & 1.90 & 0.37 & 0.59 \\ \text { Reliability } & & \text { Alpha }= & & \text { N of cases } & \begin{array}{l}\text { N of } \\ \text { Coeffcients }\end{array} \\ & & 0.63 & & 752 & \text { items:3 }\end{array}$

Mutual responsibility for and support of services (all items)

$\begin{array}{llllll}\text { 99¥ } & 1.69 & 0.50 & 0.25 & 0.33 & 0.51 \\ 100 ¥ & 1.39 & 0.64 & 0.41 & 0.32 & 0.52\end{array}$


Table 5 Reliability Analysis in Tanzania (Continued)

\begin{tabular}{clllll}
\hline Qn \# & $\begin{array}{l}\text { Scale } \\
\text { mean if } \\
\text { item } \\
\text { deleted }\end{array}$ & $\begin{array}{l}\text { Scale } \\
\text { Standard } \\
\text { Deviation }\end{array}$ & Variance & $\begin{array}{l}\text { Item total } \\
\text { Correlation } \\
\text { with Total }\end{array}$ & $\begin{array}{l}\text { Alpha } \\
\text { if item } \\
\text { deleted }\end{array}$ \\
\hline $101 ¥$ & 1.36 & 0.55 & 0.30 & 0.44 & 0.45 \\
$102 ¥$ & 1.51 & 0.53 & 0.28 & 0.39 & 0.48 \\
$103 ¥$ & 1.27 & 0.47 & 0.22 & 0.19 & 0.59 \\
Reliability Coeffcients & $\begin{array}{l}\text { Alpha }= \\
0.60\end{array}$ & & $\begin{array}{l}\text { N of cases } \\
752\end{array}$ & $\begin{array}{l}\text { N of } \\
\text { items:4 }\end{array}$ \\
\end{tabular}

* Reverse coded

** Yes/No Response items

$† 2$ Response items

$¥ 3$ Response items

Tanzania and Ghana. The item related to cost of service varied between the countries as there is a nominal fee charged in Ghana. In Tanzania, the item was 'The government ensures that family planning services are free of cost' and in Ghana it was 'The government ensures that family planning methods are free of cost.'

A total of 118 questions were asked of respondents upon leaving a facility, and only 58 scale items and 9 domains were included in the following analysis. Five domains and 17 items were excluded from this analysis because they were not scales or were items that applied after the intervention had been implemented.

The other survey items included questions about demographics, reproductive and family planning history, relationship status, income, occupation, and religion.

Client exit interviews were conducted on the day of recruitment at the facility in a private location. In Ghana, a total of 15 data collectors (5 females and 10 males) were trained in the survey over 3-day training in April 2018. In Tanzania, a total of 14 data collectors ( $8 \mathrm{fe}-$ males and 6 males) were trained over in the survey over 5 days in March 2018. Data collection was conducted using a tablet-based questionnaire to capture real-time data using OpenClinica and was later uploaded onto a secure server. Data collection in Tanzania started on 26 March and was completed on 25 May 2018, and all respondents choose to be interviewed in Kiswahili. In Ghana, data collection started on 9 April 2018 and was completed on 4 June 2018, and $46.4 \%$ choose to be interviewed in English while $53.6 \%$ choose to be interviewed in Akan.

Having being assessed for eligibility, respondents completed the informed consent process. There were no incentives given to women and girls to participate in the study. However, study participants who agreed to participate were reimbursed for their travel cost, where it was permitted by country-specific ethical requirements. In Ghana, the research team supported the travel cost to the facility with five Ghana cedis ( $\sim 1$ US dollar) given after the interview. In Tanzania, no reimbursements were given.

\section{Psychometric analysis}

We assessed the item and scale reliability followed by exploratory factor analysis (EFA) and confirmatory factor analysis (CFA) for each country. We assessed the reliability of items and scales to test the internal consistency. The EFA aimed to identify the relationships among items and then group the items as part of a factor. CFA was conducted to confirm the theory behind the grouping of items.

We started with assessing reliability using the Cronbach's alpha to determine item -to- item correlation (or homogeneity) of all 58 observed items and determined the overall alpha for each scale in each country. A Cronbach's alpha of 0.60 was considered acceptable reliability and 0.70 or higher to be good reliability [16]. Items were removed, according to standard procedures, if the overall alpha improved substantially if an item was removed [23]. Scales with Cronbach's alpha of $\geq .60$ were retained [34].

We conducted exploratory factor analysis (EFA) to determine how all 58 observed items clustered together and explore the underlying factor structure in each country. We computed the communality for each item, defined as the proportion of variance in the item attributable to common factors; and used a Kaiser-MeyerOlkin (KMO) of Sampling Adequacy to assess the suitability of items for the factor analysis. Overall, and factors with KMO value $>0.5$, for factor analysis were considered suitable for factor analysis $[19,21]$. To determine the factors, we used eigenvalues in accordance with the Kaiser Criterion [20]. We examined the eigenvalues and the scree plot of eigenvalues, and factors with Eigenvalues greater than 1.0 were retained [20].

We used a rotated factor analysis using the maximum likelihood estimation (MLE) with oblique oblimin

Table 6 Eigenvalues in Tanzania

\begin{tabular}{ll}
\hline Factor & Eigenvalue \\
\hline $\mathbf{1}$ & 23.23 \\
$\mathbf{2}$ & 20.77 \\
$\mathbf{3}$ & 15.40 \\
$\mathbf{4}$ & 8.16 \\
$\mathbf{5}$ & 6.97 \\
$\mathbf{6}$ & 4.35 \\
$\mathbf{7}$ & 3.96 \\
$\mathbf{8}$ & 2.99 \\
$\mathbf{9}$ & 2.38 \\
$\mathbf{1 0}$ & 1.87 \\
$\mathbf{1 1}$ & 1.69 \\
\hline
\end{tabular}




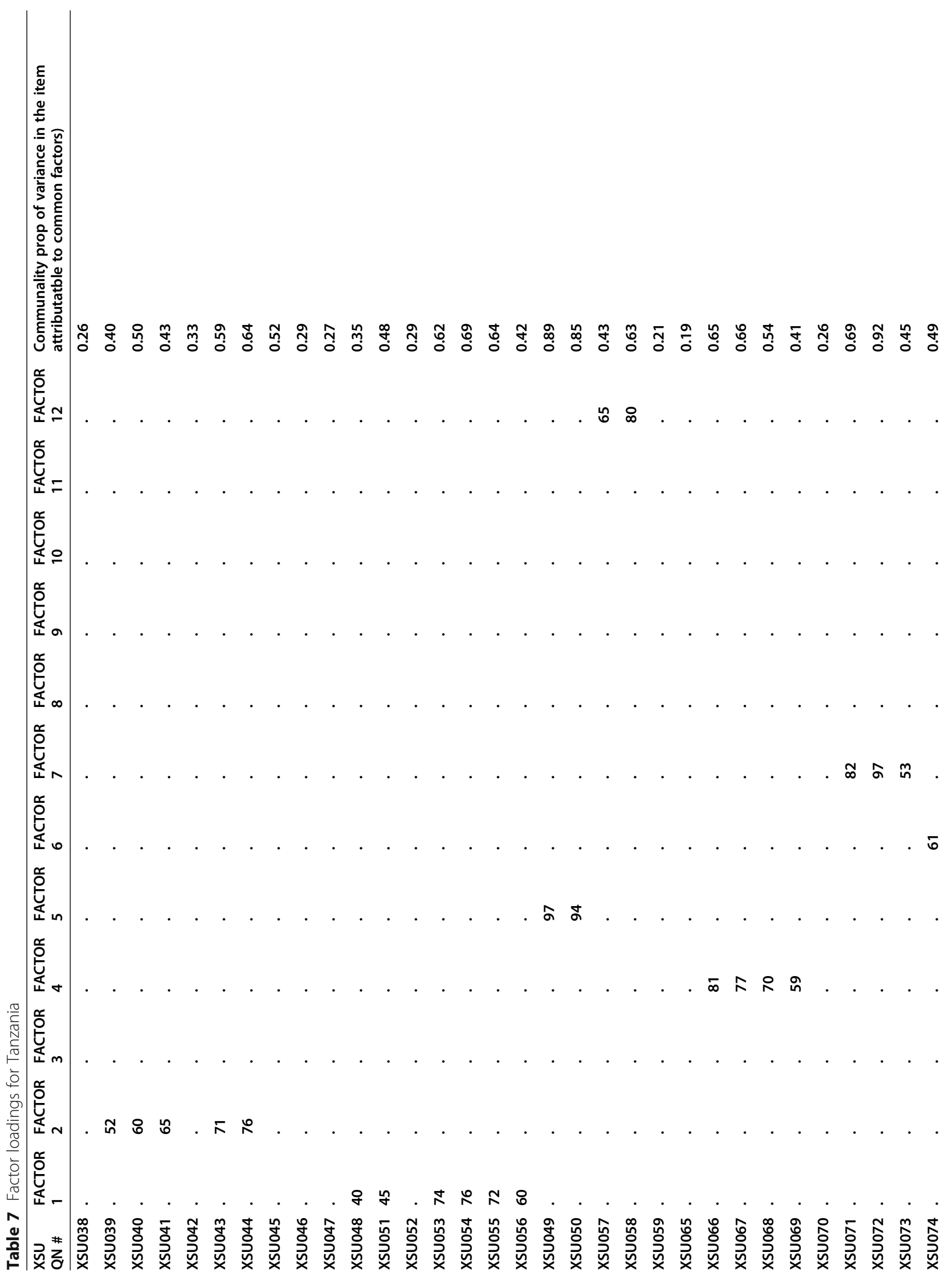




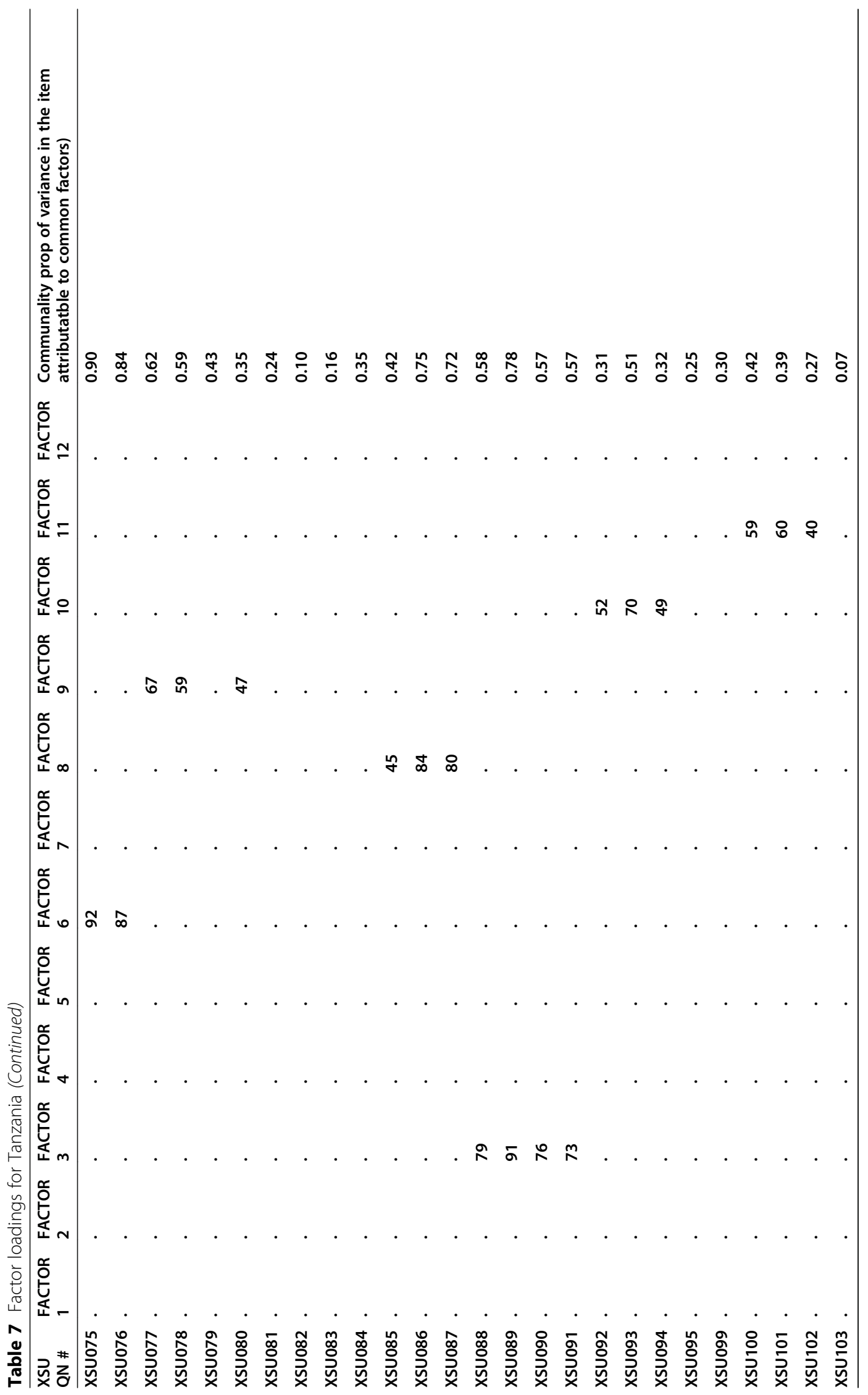


rotation to determine the factor loadings and variance. Factor loadings assess how items are weighted for each factor and the correlation between the variables and the factor. We used the proportion of variance in the item explained by the factors jointly to assess the reliability of the item in the context of all the factors. Items with factor loadings with values less than 0.40 were excluded. A minimum of three items per factor is recommended, and factors with two items or less were excluded [26].

Confirmatory Factor Analysis (CFA) was done to confirm whether the constructs identified in EFA had a good fit statistically. We applied three recommended models to test for goodness-of-fit [32]. The Standardized Root Mean Square Residual (SRMR) is a measure of the mean absolute correlation residual with a threshold of $\leq 0.08$; the Root Mean Square Error of Approximation (RMSEA) measures the estimated discrepancy between the population and model-implied population covariance matrices per degree of freedom, and a score of $\leq 0.06$ is acceptable, and Comparative Fit Index (CFI) measures the relative improvement in the fit of a researcher's model over that of a baseline model, and a CFI $\geq 0.95$ considered an acceptable fit [6]. The CFA structural model was is presented for each country.

\section{Results}

\section{Demographic characteristics}

In total, 750 in Ghana, and 752 women in Tanzania completed the survey. This sample is based on 10 respondents per item to produce a reliable estimate [6]. Table 4 shows the demographic characteristics of respondents.

The mean age of the women that participated in the survey was 28.4 in Ghana and 27.8 in Tanzania. In Tanzania, $84.8 \%$ of women were currently married compared to $63.5 \%$ in Ghana. A higher percentage of women in Tanzania were never-married (30.0\%) than Ghana
$(10.3 \%)$. In both countries, injectable and implants were the predominant current contraceptive method.

\section{Analysis}

To assess the scales in Tanzania and Ghana, we conducted three sets of analyses to (1) assess the reliability of the subscales, (2) determine how many factors to retain and reduce the items, and (3) verify our proposed groupings separately per country.

\section{Tanzania}

We started with a reliability analysis using the Cronbach's alpha to determine item -to -item correlation of all 58 observed items and determine the overall alpha for each subscales in Tanzania (see Table 5). The standardized alpha was greater than 0.60 (the acceptable reliability in social science research) for 6 of the 11 subscales and was retained. When the alpha was lesser than 0.70 , items were removed if their removal improved the overall alpha scale. A total of 6 items were removed; this included questions $38,65,70,82,83$, and 84 . Subscales with Cronbach's alpha of $\geq .60$ were retained.

We undertook a KMO measure of sampling adequacy, and all items had a KMO of 0.5. The overall KMO score was 0.85 , suggesting that there is a sufficient correlation between the variables to conduct exploratory factor analysis.

The EFA used principal factors with oblique oblimin rotation for all 58 items that yielded 11 factors. All factors had eigenvalues greater than 1.0; see Table 6 (which explained $100 \%$ of the variance).

In total, five items loaded on factor 1 , five items loaded on factor 2 , four items loaded on to factor 3 , four items loaded on to factor 4, two items loaded on to factor 5, three items loaded onto factor 6, three items loaded onto factor 7 , three items loaded onto factor 8 , three items loaded onto factor 9, three items loaded onto factor 10, and two items loaded onto factor 11 Table 7 . We discarded items with

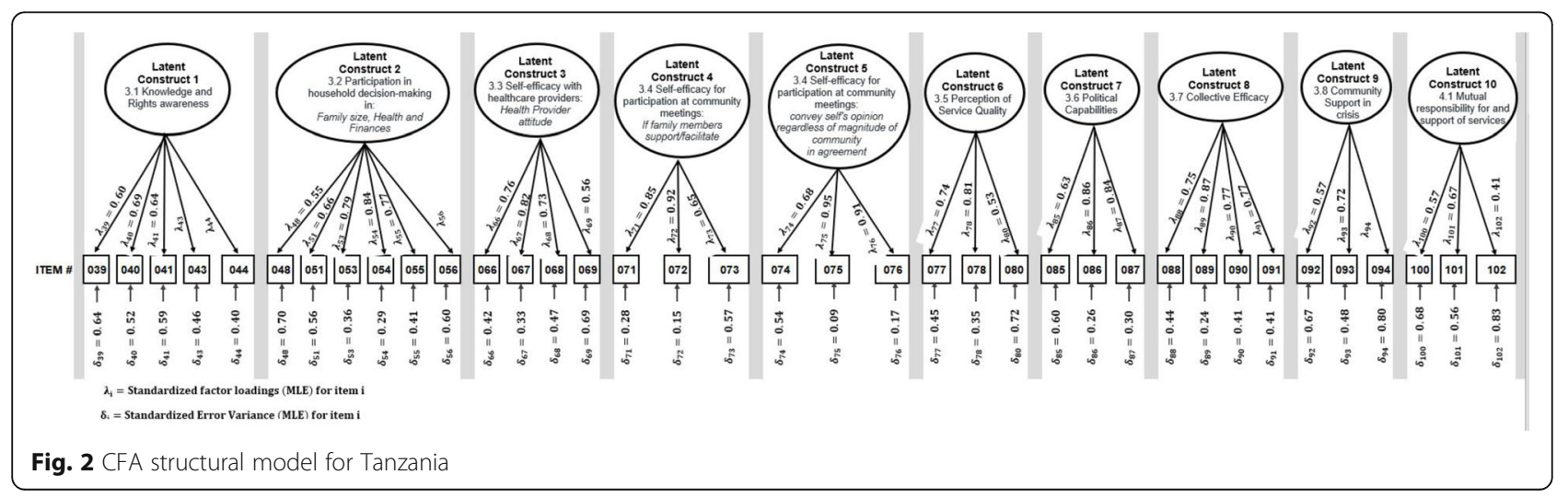


Table 8 Reliability Analysis in Ghana

\begin{tabular}{clllll}
\hline Qn \# & $\begin{array}{l}\text { Scale mean if item } \\
\text { deleted }\end{array}$ & $\begin{array}{l}\text { Scale Standard } \\
\text { Deviation }\end{array}$ & Variance & $\begin{array}{l}\text { Item total Correlation with } \\
\text { Total }\end{array}$ & $\begin{array}{l}\text { Alpha if item } \\
\text { deleted }\end{array}$ \\
\hline $\begin{array}{c}\text { Knowledge and Awareness of Rights } \\
38^{*}\end{array}$ & & & & \\
39 & 2.78 & 1.50 & 2.24 & 0.19 & 0.69 \\
40 & 2.23 & 1.19 & 1.42 & 0.13 & 0.70 \\
41 & 1.45 & 0.58 & 0.34 & 0.51 & 0.61 \\
42 & 1.64 & 0.99 & 0.99 & 0.23 & 0.68 \\
43 & 2.00 & 0.99 & 0.98 & 0.37 & 0.64 \\
44 & 1.63 & 0.71 & 0.51 & 0.54 & 0.60 \\
45 & 1.55 & 0.61 & 0.37 & 0.54 & 0.60 \\
\end{tabular}

$\begin{array}{ll}\text { Reliability Coeffcients } & \text { Alpha }=0.74 \\ \text { Women's participation in household decision-making (all items) }\end{array}$

$\begin{array}{ccc}46 \dagger & 1.78 & 0.41 \\ 47 \dagger & 1.75 & 0.44 \\ 48 \dagger & 1.82 & 0.39 \\ 49 \dagger & 1.81 & 0.39 \\ 50 \dagger & 1.78 & 0.41 \\ 51+ & 1.82 & 0.38 \\ 52 \dagger & 1.78 & 0.42 \\ 53 \dagger & 1.87 & 0.33 \\ 54 \dagger & 1.88 & 0.33 \\ 55 \dagger & 1.88 & 0.33 \\ 56 \dagger & 1.88 & 0.33 \\ \text { Reliability Coeffcients } & \text { Alpha }=0.91\end{array}$

Self efficacy with health care providers (Qn 57, 58 \& 59)

$\begin{array}{lll}57^{* *} & 0.89 & 0.31 \\ 58^{* *} & 0.96 & 1.20 \\ 59^{* *} & 0.93 & 0.26\end{array}$

Reliability

Coeffcients

Alpha $=0.71$

$\mathrm{N}$ of cases 750

$\mathrm{N}$ of items: 5

Self efficacy with health care providers (all items)

$\begin{array}{lll}65 & 1.82 & 0.98 \\ 66^{*} & 2.13 & 1.14 \\ 67^{*} & 1.94 & 0.92 \\ 68^{*} & 1.95 & 0.89 \\ 69^{*} & 2.05 & 0.98 \\ 70 & 1.49 & 0.78 \\ \text { Reliability Coeffcients } & \text { Alpha }=0.80\end{array}$

$\begin{array}{lll}0.17 & 0.69 & 0.90\end{array}$

$\begin{array}{lll}0.19 & 0.69 & 0.90\end{array}$

$\begin{array}{lll}0.15 & 0.69 & 0.90\end{array}$

$\begin{array}{lll}0.15 & 0.69 & 0.90\end{array}$

$\begin{array}{lll}0.17 & 0.69 & 0.90\end{array}$

$\begin{array}{lll}0.15 & 0.69 & 0.90\end{array}$

$\begin{array}{lll}0.17 & 0.69 & 0.91\end{array}$

$\begin{array}{lll}0.11 & 0.69 & 0.91\end{array}$

$\begin{array}{lll}0.11 & 0.69 & 0.91\end{array}$

$\begin{array}{lll}0.11 & 0.69 & 0.91\end{array}$

$\begin{array}{lll}0.11 & 0.69 & 0.91\end{array}$

0.91

N of cases $750 \quad N$ of items: 10

$\begin{array}{lll}0.10 & 0.50 & 0.65\end{array}$

$\begin{array}{lll}1.44 & 0.64 & 0.46\end{array}$

$\begin{array}{lll}0.07 & 0.44 & 0.72\end{array}$

N of cases $750 \quad N$ of items: 2

Self-efficacy for participation at community meetings (all items)(Qn 71-73)

\begin{tabular}{|c|c|c|c|c|c|}
\hline 71 & 2.44 & 1.65 & 2.72 & 0.73 & 0.85 \\
\hline 72 & 2.60 & 1.63 & 2.66 & 0.80 & 0.83 \\
\hline 73 & 2.60 & 1.62 & 2.62 & 0.60 & 0.91 \\
\hline elial & & Alph & & $\mathrm{N}$ of cases 750 & $N$ of items:2 \\
\hline
\end{tabular}

Self-efficacy for participation at community meetings (all items) 
Table 8 Reliability Analysis in Ghana (Continued)

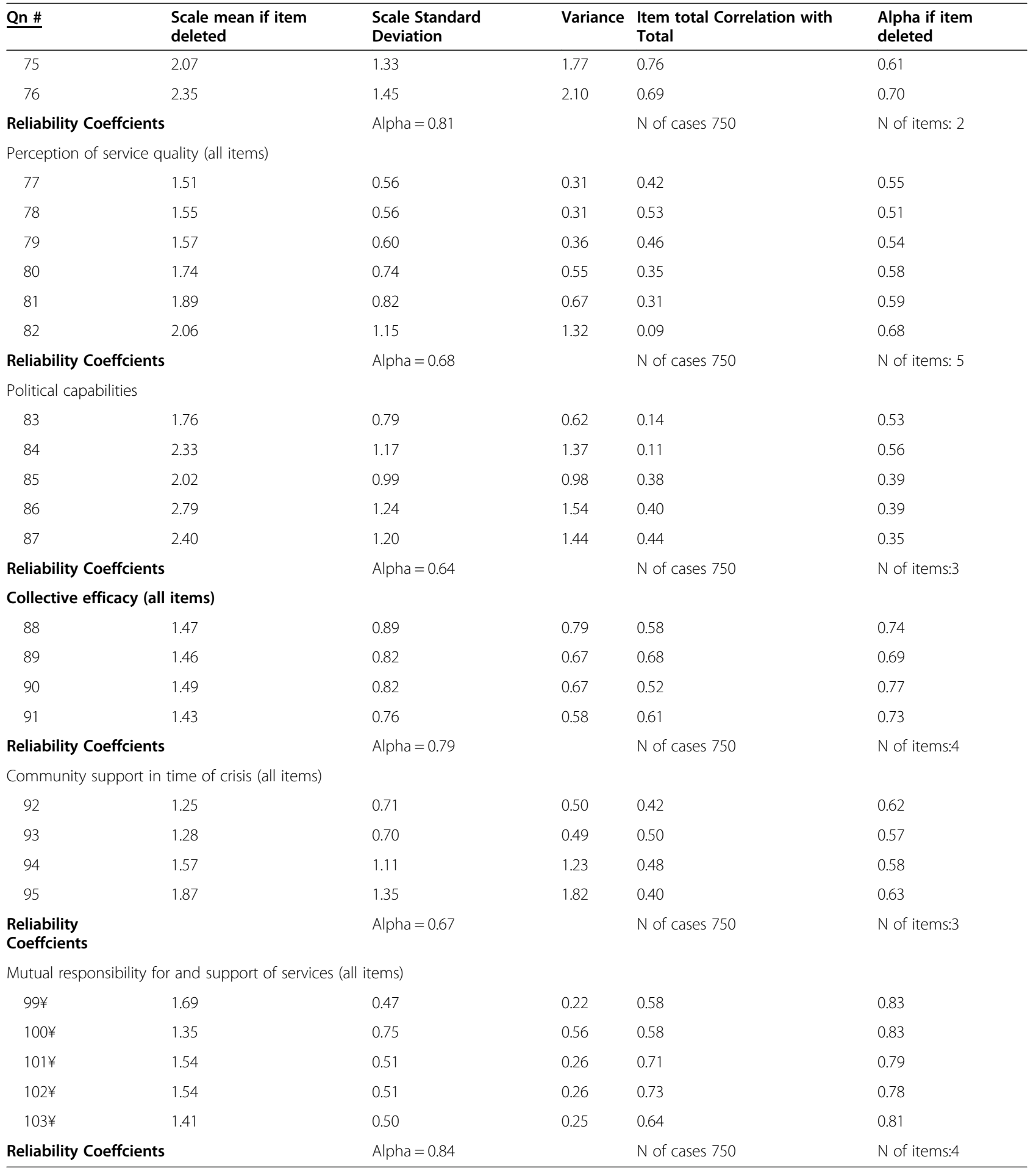

* Reverse coded

** Yes/No Response items

† 2 Response items

$¥ 3$ Response items

factor loadings of less than 0.4 , and 12 items were removed, see Table 7 . Factors with less than two items were excluded as this is not a sufficient number for factor analysis. On this basis, two factors were removed, and 10 factors were retained. A total of 40 items were retained. 
To name the factors, we assessed what items were retained from the reliability analysis and the exploratory factor analysis and the original domain groupings. Factor 1 continues to reflect the domain items related to a client's knowledge of their health rights and is named 'Knowledge of health rights.' The items included in factor 2 reflected knowledge of household decision-making in relation to finances and sexual and reproductive health and retained the name 'Women's participation in household decision-making'. The items included in factor 4 relate to clients' perceived mistreatment by health care providers and is named 'Mistreatment by health workers'. Items in factor 5 relate to the clients' ability to attend a community meeting and are named 'Ability to attend a community meeting.' Factor 6 included items related to the ability to actively participate in a community meeting and is named 'Ability to participate in a community meeting.' Items in factor 7 relate to the client's 'Perception of quality' and retain the name, 'Perception of quality services'. The items in factor 8 relate to the understanding of how to bring about change in contraceptive clinics and are named 'Awareness of accountability mechanisms.' Factor 9 includes items that relate to the sense of social capital and cohesion and retains the name 'Collective efficacy'. Factor 10 included items related to a sense of support from others during a crisis and retains the name 'Community support in the time of crisis.' For factor 11, the items related to how clients thought change could be achieved and retains the name 'Mutual responsibility for and support of services' (Fig. 2).

\section{Ghana}

We started with a reliability analysis using the Cronbach's alpha to determine item -to- item correlation of all 58 observed items and determined the overall alpha for each subscales in Ghana (see Table 8). The standardized alpha was greater than 0.60 for 8 of the 11 subscales and was retained. When the alpha was lesser than 0.60 , items were removed if their removal improved the overall alpha scale. A total of 8 items were removed; this included questions $38,39,41,65,70,82,83$, and 84 . Scales with Cronbach's alpha of $\geq .60$ were retained.

In the KMO measure of sampling adequacy, all items had a KMO of 0.5 , and the overall KMO score was 0.80 , suggesting that there is sufficient correlation between the variables to conduct exploratory factor analysis.

The EFA used principal factors with oblique oblimin rotation yielded 13 factors with eigenvalues greater than or equal to 1.0 (see Table 9).

The revised item data was used in the confirmatory factor analysis to analyze a good fit. The SRMR score of 0.05, the CFI score of 0.94, and the RMSEA score of
Table 9 Eigenvalues in Ghana

\begin{tabular}{ll}
\hline Factor & Eigenvalue \\
\hline $\mathbf{1}$ & 18.47 \\
$\mathbf{2}$ & 13.98 \\
$\mathbf{3}$ & 11.17 \\
$\mathbf{4}$ & 7.68 \\
$\mathbf{5}$ & 6.27 \\
$\mathbf{6}$ & 5.43 \\
$\mathbf{7}$ & 4.18 \\
$\mathbf{8}$ & 3.78 \\
$\mathbf{9}$ & 2.60 \\
$\mathbf{1 0}$ & 2.32 \\
$\mathbf{1 1}$ & 1.99 \\
$\mathbf{1 2}$ & 1.45 \\
$\mathbf{1 3}$ & 1.31 \\
\hline
\end{tabular}

0.03 are good. All three score suggests acceptable goodness-of-fit.

In total, seven items loaded on factor 1 , five items loaded on factor 2, three items loaded on to factor 3, four items loaded on to factor 4 , four items loaded on to factor 5, five items loaded onto factor 6 , three items loaded onto factor 7 , three items loaded onto factor 8 , three items loaded onto factor 9, four items loaded onto factor 10, four items loaded onto factor 11, two items on factor 12 and one item on factor 13 Table 10. Factors with less than two items were excluded as this is not sufficient for factor analysis, this reduced the number of factors from 13 to 10 . We discarded items with factor loadings less than 0.4 , and two items were removed, see Table 11. In total, 10 items were removed, and 48 items were retained.

Similar to Tanzania, to name the factors, we assessed what items were retained and the original domains. These corresponded with those found in Tanzania, with the exception of one factor that was dropped in Tanzania but retained in Ghana. The items included in this factor related to a clients' sense of activation and are named 'patient activation.' There was also a difference in what items were retained in relation to household decision making; those pertaining to contraception were excluded, whereas those related to decisions over finances, over seeking health care, and visiting others were included (Fig. 3).

The revised item data was used in the confirmatory factor analysis to assess the goodness-of-fit. The SRMR score of 0.057 , the CFI score of 0.88 , and the RMSEA score of 0.04 , all suggest an acceptable goodness-of-fit. 


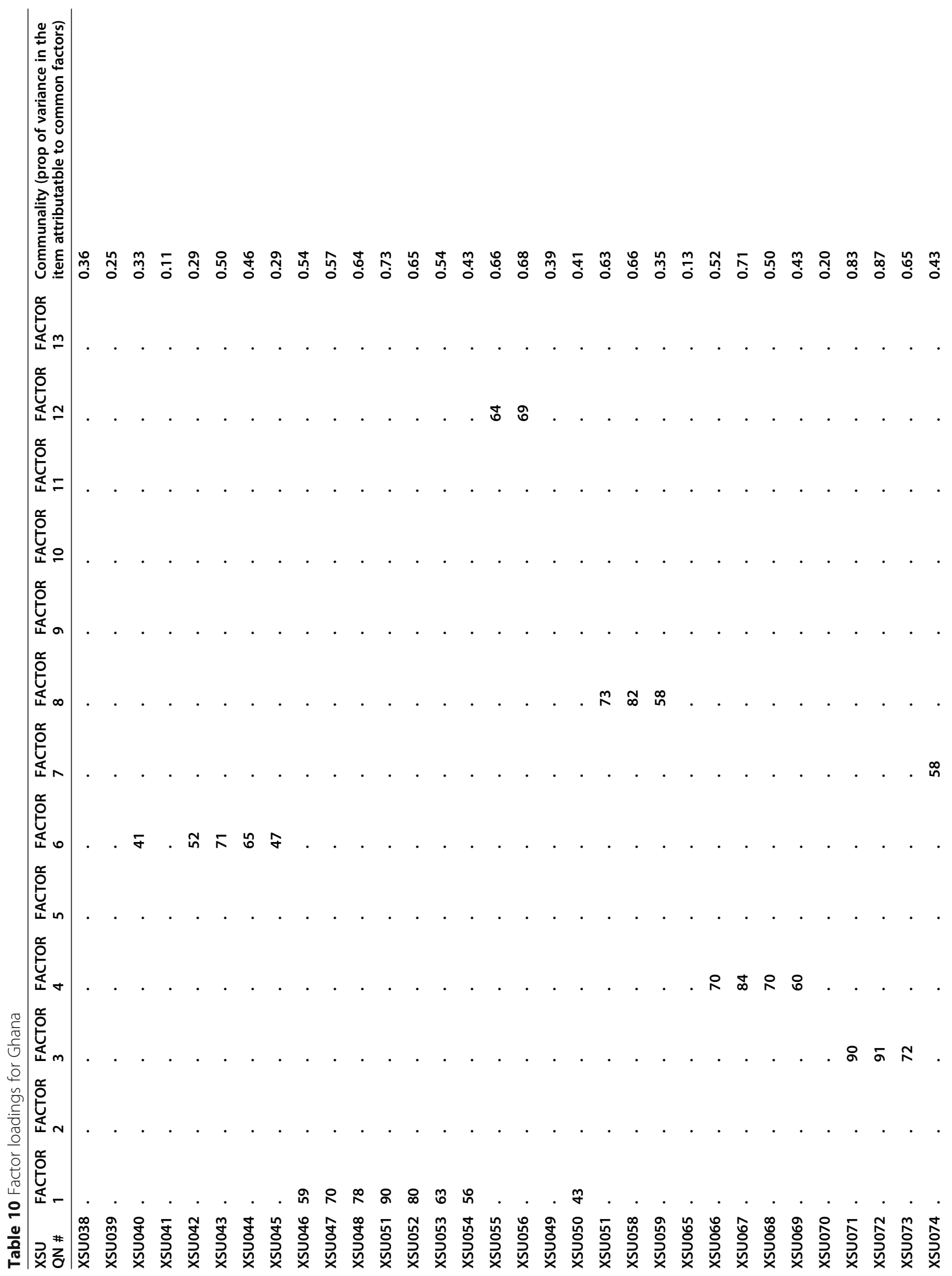




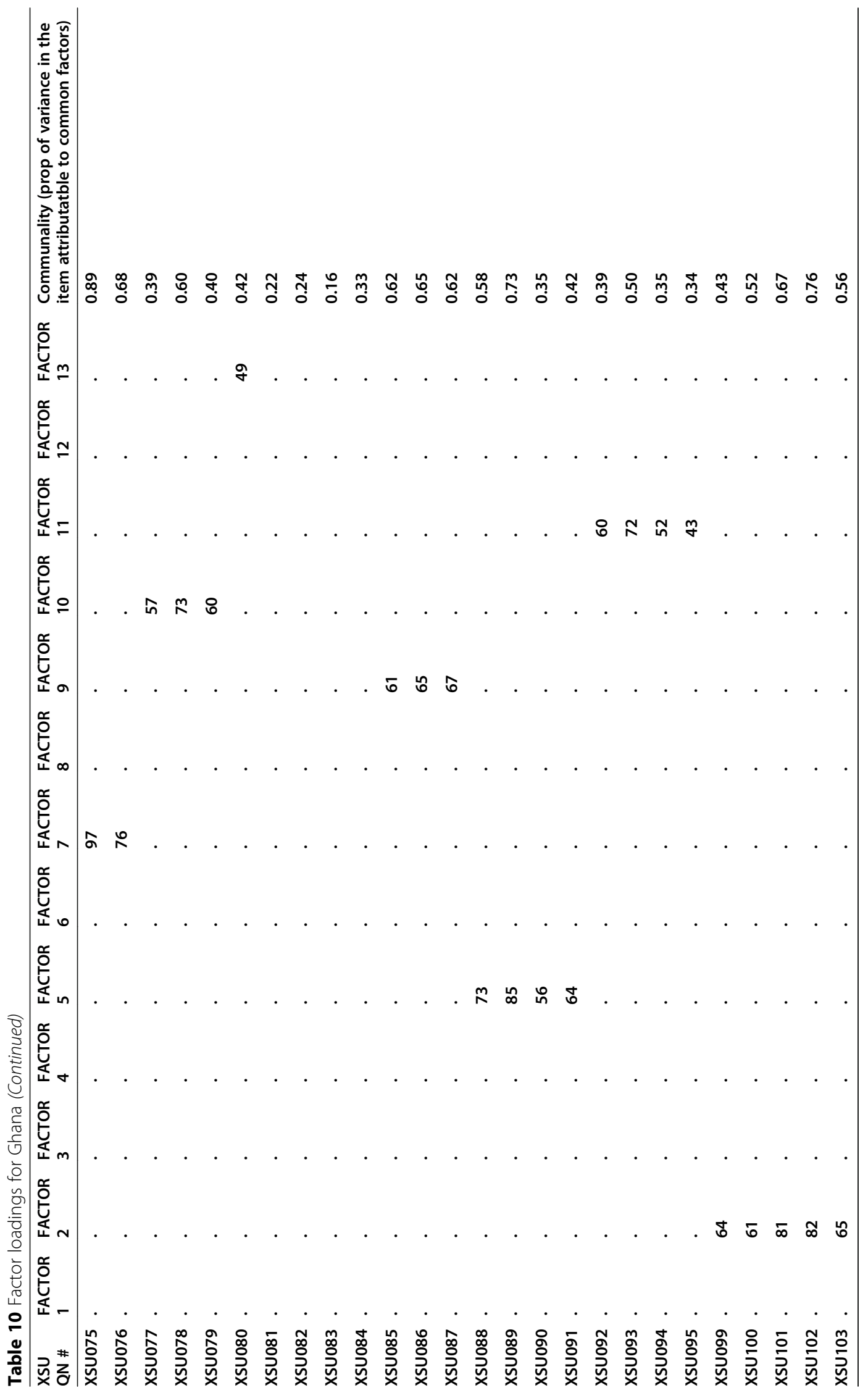


Table 11 Final items per country

\begin{tabular}{|c|c|c|c|c|c|c|c|}
\hline \multicolumn{4}{|c|}{ Tanzania } & \multicolumn{4}{|c|}{ Ghana } \\
\hline & Item & $\begin{array}{l}\text { CFA } \\
\text { Factor } \\
\text { loading }\end{array}$ & $\begin{array}{l}\text { Standard } \\
\text { Error } \\
\text { Variance }\end{array}$ & & Item & $\begin{array}{l}\text { CFA } \\
\text { Factor } \\
\text { loading }\end{array}$ & $\begin{array}{l}\text { Standard } \\
\text { Error } \\
\text { Variance }\end{array}$ \\
\hline
\end{tabular}

\section{Knowledge of Health Rights}

A healthcare provider can refuse to

XSU038 provide me family planning services because of who I am. (reverse-coded)

The government ensures that family

XSU039 planning methods (Ghana) or services (Tanzania) are free of cost.

I have the right to privacy during my $\quad 0.69 \quad 0.52$

XSU040 family planning visit.

The healthcare provider should not

XSU041 share my information with other people.

If I am unhappy with the care I

XSU042 received, I know there are ways to make a complaint.

$\begin{array}{lll}\text { Healthcare providers must answer all } & 0.73 & 0.46\end{array}$

XSU043 my health related questions.

Healthcare providers should inform me

XSU044 about the different family planning options.

I can refuse any family planning

XSU045 method offered if I do not want to use it.

\section{Mistreatment by Health workers}

I felt like I could discuss my problems,

XSU065 question and concerns with the health care provider without feeling embarrassed.

One of the providers or staff refused to 0.76

XSU066 offer me the service I wanted to receive. (reverse-coded)

The provider ignored my request or my 0.82

XSU067 preferences today.

$\begin{array}{lll}\text { I felt like the provider did not listen to } & 0.73 & 0.47\end{array}$

XSU068 what I was saying (reverse-coded)

A provider strongly encouraged me to

XSU069 use one family planning that was different to the one I wanted (reversecoded)

I have the right to choose my family

XSU070 planning method.

\section{Perception of quality services}

The staff at this health facility have high 0.74

XSU077 quality family planning services.

$\begin{array}{lll}\text { The staff at this health facility ensures } & 0.81 & 0.35\end{array}$

XSU078 privacy and confidentiality when providing services.

The health facility is clean.

At this health facility, if women choose,

XSU080 they can bring their husband/partner for the family planning consultation.

At this health facility, if women choose,
XSU038 A healthcare provider can refuse to provide me family planning services because of who I am. (reverse-coded)

XSU039 The government ensures that family planning methods (Ghana) or services (Tanzania) are free of cost.

XSU040 I have the right to privacy during my family planning visit.

XSU041 The healthcare provider should not share my information with other people.

XSU042 If I am unhappy with the care I received, I know there are ways to make a complaint.

XSU043 Healthcare providers must answer all my health related questions.

XSU044 Healthcare providers should inform me about the different family planning options.

XSU045 I can refuse any family planning method offered if I do not want to use it.

XSU065 I felt like I could discuss my problems, question and concerns with the health care provider without feeling embarrassed.

XSU066 One of the providers or staff refused to 0.71 offer me the service I wanted to receive. (reverse-coded)

$\begin{array}{llll}\text { XSU067 The provider ignored my request or my } & 0.86 & 0.26\end{array}$ preferences today.

XSU068 I felt like the provider did not listen to $0.66 \quad 0.56$ what I was saying (reverse-coded)

XSU069 A provider strongly encouraged me to use one family planning that was different to the one I wanted (reversecoded)

XSU070 I have the right to choose my family planning method.

XSU077 The staff at this health facility have high 0.62 quality family planning services.

xSU078 The staff at this health facility ensures privacy and confidentiality when providing services.

xSU079 The health facility is clean.

XSU080 At this health facility, if women choose, they can bring their husband/partner for the family planning consultation.

XSU081 At this health facility, if women choose, 
Table 11 Final items per country (Continued)

\begin{tabular}{|c|c|c|c|c|c|c|c|}
\hline \multicolumn{4}{|l|}{ Tanzania } & \multicolumn{4}{|l|}{ Ghana } \\
\hline No & Item & $\begin{array}{l}\text { CFA } \\
\text { Factor } \\
\text { loading }\end{array}$ & $\begin{array}{l}\text { Standard } \\
\text { Error } \\
\text { Variance }\end{array}$ & No & Item & $\begin{array}{l}\text { CFA } \\
\text { Factor } \\
\text { loading }\end{array}$ & $\begin{array}{l}\text { Standard } \\
\text { Error } \\
\text { Variance }\end{array}$ \\
\hline XSU081 & $\begin{array}{l}\text { they can bring a family member or } \\
\text { friend for the family planning } \\
\text { consultation. }\end{array}$ & & & & $\begin{array}{l}\text { they can bring a family member or } \\
\text { friend for the family planning } \\
\text { consultation. }\end{array}$ & & \\
\hline XSU082 & $\begin{array}{l}\text { Unmarried women can access family } \\
\text { planning and reproductive health } \\
\text { service at the health facility. }\end{array}$ & & & XSU082 & $\begin{array}{l}\text { Unmarried women can access family } \\
\text { planning and reproductive health } \\
\text { service at the health facility. }\end{array}$ & & \\
\hline \multicolumn{8}{|c|}{ Women's participation in $\mathrm{h} / \mathrm{h}$ decision-making } \\
\hline XSU046 & $\begin{array}{l}\text { First, would you tell me which member } \\
\text { of your household usually makes } \\
\text { decisions about your health care? }\end{array}$ & & & XSU046 & $\begin{array}{l}\text { First, would you tell me which member } \\
\text { of your household usually makes } \\
\text { decisions about your health care? }\end{array}$ & & 0.49 \\
\hline XsU047 & $\begin{array}{l}\text { Which member of your household } \\
\text { usually makes decisions about making } \\
\text { large household purchases? }\end{array}$ & & & XSU047 & $\begin{array}{l}\text { Which member of your household } \\
\text { usually makes decisions about making } \\
\text { large household purchases? }\end{array}$ & 0.75 & 0.44 \\
\hline XSU048 & $\begin{array}{l}\text { Which member of your household } \\
\text { usually makes decisions about making } \\
\text { household purchases for daily needs? }\end{array}$ & 0.55 & 0.7 & XSU048 & $\begin{array}{l}\text { Which member of your household } \\
\text { usually makes decisions about making } \\
\text { household purchases for daily needs? }\end{array}$ & 0.8 & 0.36 \\
\hline XSU049 & $\begin{array}{l}\text { Which member of your household } \\
\text { usually makes decisions about when } \\
\text { you will visit family/relatives/friends? }\end{array}$ & & & XSU049 & $\begin{array}{l}\text { Which member of your household } \\
\text { usually makes decisions about when } \\
\text { you will visit family/relatives/friends? }\end{array}$ & 0.83 & 0.32 \\
\hline XSU050 & $\begin{array}{l}\text { Which member of your household } \\
\text { usually makes decisions about when } \\
\text { your whole household will visit family/ } \\
\text { relatives/friends? }\end{array}$ & & & XSU050 & $\begin{array}{l}\text { Which member of your household } \\
\text { usually makes decisions about when } \\
\text { your whole household will visit family/ } \\
\text { relatives/friends? }\end{array}$ & 0.74 & 0.45 \\
\hline XSU051 & $\begin{array}{l}\text { Which member of your household } \\
\text { usually makes decisions about how to } \\
\text { use the money that you bring into the } \\
\text { household? }\end{array}$ & 0.66 & 0.56 & XSU051 & $\begin{array}{l}\text { Which member of your household } \\
\text { usually makes decisions about how to } \\
\text { use the money that you bring into the } \\
\text { household? }\end{array}$ & 0.73 & 0.47 \\
\hline XSU052 & $\begin{array}{l}\text { Which member of your household } \\
\text { usually makes decisions about how to } \\
\text { use the money your husband/partner } \\
\text { brings into the household? }\end{array}$ & & & XSU052 & $\begin{array}{l}\text { Which member of your household } \\
\text { usually makes decisions about how to } \\
\text { use the money your husband/partner } \\
\text { brings into the household? }\end{array}$ & 0.64 & 0.59 \\
\hline XSU053 & $\begin{array}{l}\text { Which member of your household } \\
\text { usually makes decisions about whether } \\
\text { you or you and your husband/partner } \\
\text { use family planning? }\end{array}$ & 0.79 & 0.36 & XSU053 & $\begin{array}{l}\text { Which member of your household } \\
\text { usually makes decisions about whether } \\
\text { you or you and your husband/partner } \\
\text { use family planning? }\end{array}$ & & \\
\hline XSU054 & $\begin{array}{l}\text { Which member of your household } \\
\text { usually makes decisions about where } \\
\text { you will receive family planning? }\end{array}$ & 0.84 & 0.29 & XSU054 & $\begin{array}{l}\text { Which member of your household } \\
\text { usually makes decisions about where } \\
\text { you will receive family planning? }\end{array}$ & & \\
\hline XSU055 & $\begin{array}{l}\text { Which member of your household } \\
\text { usually makes decisions about if you } \\
\text { will be tested for the AIDS virus? }\end{array}$ & 0.77 & 0.41 & XSU055 & $\begin{array}{l}\text { Which member of your household } \\
\text { usually makes decisions about if you } \\
\text { will be tested for the AIDS virus? }\end{array}$ & & \\
\hline XSU056 & $\begin{array}{l}\text { Which member of your household } \\
\text { usually makes decisions about how } \\
\text { many children you will have? }\end{array}$ & 0.63 & 0.6 & XSU056 & $\begin{array}{l}\text { Which member of your household } \\
\text { usually makes decisions about how } \\
\text { many children you will have? }\end{array}$ & 0.59 & 0.66 \\
\hline \multicolumn{8}{|c|}{ Self efficacy with health care providers } \\
\hline XSU057 & $\begin{array}{l}\text { After your consultation with the health } \\
\text { care provider today, do you know what } \\
\text { your reproductive and family planning } \\
\text { options are? }\end{array}$ & & & XSU057 & $\begin{array}{l}\text { After your consultation with the health } \\
\text { care provider today, do you know what } \\
\text { your reproductive and family planning } \\
\text { options are? }\end{array}$ & 0.73 & 0.47 \\
\hline XSU058 & $\begin{array}{l}\text { After your consultation with the health } \\
\text { care provider today, do you feel that } \\
\text { you can act on your choice for family } \\
\text { planning? }\end{array}$ & & & XSU058 & $\begin{array}{l}\text { After your consultation with the health } \\
\text { care provider today, do you feel that } \\
\text { you can act on your choice for family } \\
\text { planning? }\end{array}$ & 0.87 & 0.24 \\
\hline XSU059 & $\begin{array}{l}\text { Do you know what help you need to } \\
\text { make a decision? }\end{array}$ & & & XSU059 & $\begin{array}{l}\text { Do you know what help you need to } \\
\text { make a decision? }\end{array}$ & 0.54 & 0.71 \\
\hline
\end{tabular}


Table 11 Final items per country (Continued)

\begin{tabular}{ll}
\hline Tanzania & \\
\hline No & Item \\
\hline Ability to atttend community meetings \\
XSU071 $\begin{array}{l}\text { How sure are you that you could } \\
\text { family did not support you to }\end{array}$ \\
participate? \\
How sure are you that you could \\
XSU72 \\
attend a community meeting if your \\
family said you could not go? \\
How sure are you that you could \\
attend a community meeting if your \\
family would not help with your \\
household duties so that you could \\
attend?
\end{tabular}

\section{Ability to participate in community meetings}

How sure are you that you could

XSU074 express your opinion at a community meeting?

How sure are you that you could

XSU075 express your opinion at a community meeting if a few people did not agree

How sure are you that you could

XSU076 express your opinion at a community meeting if many people did not agree with what you were saying?

\section{Awareness of accountabilty mechanisms}

Today, if I went to the clinic I believe I

XSU083 could get family planning I wanted without facing any barriers of cost, age and marital status.

XSU084 or community members, can help you access your right to quality family planning services.

Health providers and district influence the quality of your local family planning services?

Challenging people of influence is the

XSU086 best way to change family planning services in the clinic.

Collaboration with people of influence

XSU087 is the best way to change family planning services in the clinic.

0.68

0.95 with what you were saying?

Anyone outside of the clinic, like friends

XSU085 government officials can directly

$\begin{array}{lllll} & & \text { Ghana } & \\ \text { CFA } & \text { Standard } & & \text { No } & \text { Item } \\ \text { loading } & \text { Error } & & & \\ \text { Variance } & & \end{array}$

0.85

0.92

0.65

0.57

17

XSU076 How sure are you that you could

XSU071

are you that you could attend a community meeting if your family did not support you to participate?

XSU072 How sure are you that you could attend a community meeting if your family said you could not go?

XSU073 How sure are you that you could attend a community meeting if your family would not help with your household duties so that you could attend?

XSU074 How sure are you that you could express your opinion at a community meeting?

XSU075 How sure are you that you could express your opinion at a community meeting if a few people did not agree with what you were saying? express your opinion at a community meeting if many people did not agree with what you were saying?

XSU083 Today, if I went to the clinic I believe I could get family planning I wanted without facing any barriers of cost, age and marital status.

XSU084 Anyone outside of the clinic, like friends or community members, can help you access your right to quality family planning services.

XSU085 Health providers and district government officials can directly influence the quality of your local family planning services?

XSU086 Challenging people of influence is the best way to change family planning services in the clinic.

XSU087 Collaboration with people of influence is the best way to change family planning services in the clinic.

Mutual responsibility for and support of services (all items)

Who could have the most impact on

XSU099 making sure that women are treated with respect by health workers?

$\begin{array}{lll}\text { Who could have the most impact on } & 0.57 & 0.68\end{array}$

XSU100 making sure that women have transportation to the hospital for permanent methods of contraception?

Who could have the most impact on $\quad 0.67 \quad 0.56$

XSU101 increasing the number of days a health worker visits your community?

$0.67 \quad 0.56$

XSU099 Who could have the most impact on making sure that women are treated with respect by health workers?

XSU100 Who could have the most impact on making sure that women have transportation to the hospital for permanent methods of contraception?

XSU101 Who could have the most impact on increasing the number of days a health worker visits your community? 
Table 11 Final items per country (Continued)

\begin{tabular}{|c|c|c|c|c|c|c|c|}
\hline \multicolumn{4}{|l|}{ Tanzania } & \multicolumn{4}{|l|}{ Ghana } \\
\hline No & Item & $\begin{array}{l}\text { CFA } \\
\text { Factor } \\
\text { loading }\end{array}$ & $\begin{array}{l}\text { Standard } \\
\text { Error } \\
\text { Variance } \\
\end{array}$ & No & Item & $\begin{array}{l}\text { CFA } \\
\text { Factor } \\
\text { loading }\end{array}$ & $\begin{array}{l}\text { Standard } \\
\text { Error } \\
\text { Variance }\end{array}$ \\
\hline XSU102 & $\begin{array}{l}\text { Who could have the most impact on } \\
\text { making sure the poorest and most } \\
\text { vulnerable women in the community } \\
\text { receive care? }\end{array}$ & 0.41 & 0.83 & XSU102 & $\begin{array}{l}\text { Who could have the most impact on } \\
\text { making sure the poorest and most } \\
\text { vulnerable women in the community } \\
\text { receive care? }\end{array}$ & 0.87 & 0.24 \\
\hline XSU103 & $\begin{array}{l}\text { Who could have the most impact on } \\
\text { getting funding to improve health } \\
\text { services in this community? }\end{array}$ & & & XSU103 & $\begin{array}{l}\text { Who could have the most impact on } \\
\text { getting funding to improve health } \\
\text { services in this community? }\end{array}$ & 0.71 & 0.46 \\
\hline \multicolumn{8}{|c|}{ Collective efficacy } \\
\hline XSU088 & $\begin{array}{l}\text { How sure are you that the people in } \\
\text { your community could work together } \\
\text { to improve family planning services in } \\
\text { this community? }\end{array}$ & 0.75 & 0.44 & XSU088 & $\begin{array}{l}\text { How sure are you that the people in } \\
\text { your community could work together } \\
\text { to improve family planning services in } \\
\text { this community? }\end{array}$ & 0.75 & 0.44 \\
\hline XSU089 & $\begin{array}{l}\text { How sure are you that the people in } \\
\text { your community could work together } \\
\text { to improve how women are treated at } \\
\text { the health facility? }\end{array}$ & 0.87 & 0.24 & XSU089 & $\begin{array}{l}\text { How sure are you that the people in } \\
\text { your community could work together } \\
\text { to improve how women are treated at } \\
\text { the health facility? }\end{array}$ & 0.85 & 0.28 \\
\hline XSU090 & $\begin{array}{l}\text { How sure are you that the people in } \\
\text { your community could work together } \\
\text { to obtain government services and } \\
\text { entitlements? }\end{array}$ & 0.77 & 0.41 & XSU090 & $\begin{array}{l}\text { How sure are you that the people in } \\
\text { your community could work together } \\
\text { to obtain government services and } \\
\text { entitlements? }\end{array}$ & 0.55 & 0.7 \\
\hline XSU091 & $\begin{array}{l}\text { How sure are you that the people in } \\
\text { your community could work together } \\
\text { to improve the health and well-being } \\
\text { of women in this community? }\end{array}$ & 0.77 & 0.41 & XSU091 & $\begin{array}{l}\text { How sure are you that the people in } \\
\text { your community could work together } \\
\text { to improve the health and well-being } \\
\text { of women in this community? }\end{array}$ & 0.63 & 0.61 \\
\hline \multicolumn{8}{|c|}{ Community Support in the time of crisis } \\
\hline XSU092 & $\begin{array}{l}\text { How sure are you that there is } \\
\text { someone in your community, apart } \\
\text { from your immediate family, who you } \\
\text { could go to for advice? }\end{array}$ & & & XSU092 & $\begin{array}{l}\text { How sure are you that there is } \\
\text { someone in your community, apart } \\
\text { from your immediate family, who you } \\
\text { could go to for advice? }\end{array}$ & 0.6 & 0.64 \\
\hline XSU093 & $\begin{array}{l}\text { How sure are you that there is } \\
\text { someone in your community, apart } \\
\text { from your immediate family, who could } \\
\text { take you to the clinic? }\end{array}$ & 0.57 & 0.67 & XSU093 & $\begin{array}{l}\text { How sure are you that there is } \\
\text { someone in your community, apart } \\
\text { from your immediate family, who could } \\
\text { take you to the clinic? }\end{array}$ & 0.66 & 0.57 \\
\hline XSU094 & $\begin{array}{l}\text { How sure are you that there is } \\
\text { someone in your community, apart } \\
\text { from your immediate family, who } \\
\text { would help care for your children or } \\
\text { household while you are away? }\end{array}$ & 0.72 & 0.48 & XSU094 & $\begin{array}{l}\text { How sure are you that there is } \\
\text { someone in your community, apart } \\
\text { from your immediate family, who } \\
\text { would help care for your children or } \\
\text { household while you are away? }\end{array}$ & 0.56 & 0.69 \\
\hline XSU095 & $\begin{array}{l}\text { How sure are you that there is } \\
\text { someone in your community, apart } \\
\text { from your immediate family, who } \\
\text { would loan you money for transport? }\end{array}$ & 0.44 & 0.8 & XSU095 & $\begin{array}{l}\text { How sure are you that there is } \\
\text { someone in your community, apart } \\
\text { from your immediate family, who } \\
\text { would loan you money for transport? }\end{array}$ & 0.51 & 0.74 \\
\hline
\end{tabular}

\section{Discussion}

We adapted and validated the measures of service users' attitudes and behaviors in a social accountability process to improve contraceptive services in Ghana and Tanzania. The measure has high construct validity and reliability in both countries. We identified several subscales in both countries: 10 subscales in Tanzania and 11 subscales in Ghana. Many of the scales and items were shared across both settings, as shown in Table 11 . There were some differences in how the scales performed in the different contexts; however, there was convergence in the analysis to suggest that this measure may be relevant to other settings.

The first group of scales related to clients' awareness about their health and contraceptive entitlements. This includes the following scales: knowledge of health rights, mistreatment by health workers, and perception of quality. While these scales are conceptually distinct constructs, when combined, they measure a critical aspect of clients' knowledge of their rights and entitlements. In the social accountability canon, being aware of one's health rights and entitlements is a critical precursor to 


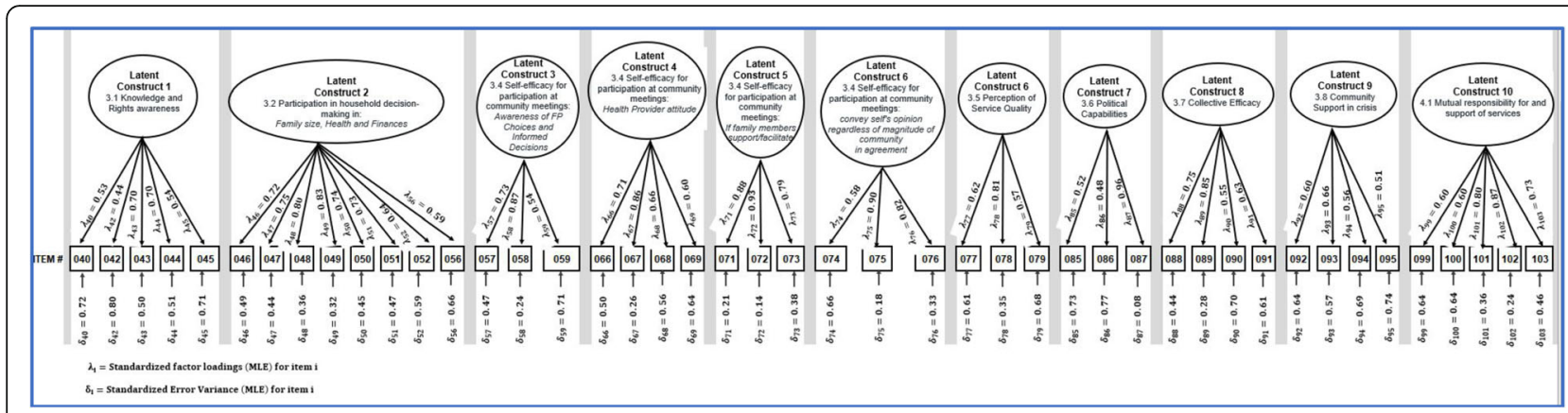

Fig. 3 CFA structural model for Ghana

generating critical consciousness and people's ability to participate in collective action [9, 12, 14, 29]. As George [12] reminds us, "Not only is access to information essential for improving health awareness and access, it is impossible to mobilise for change without it. People cannot demand services and accountability if they do not know what they need and what they are entitled to."

Several of the scales related to capturing an individual's perception of their ability to affect change are included: 'Women's participation in household decisionmaking', 'Self-efficacy with health care providers', 'Ability to attend community meetings', and 'Ability to participate in community meetings'. There was also a group of scales related to if clients knew how to improve their existing circumstance and included: 'Mutual responsibility for and support of services' and 'Awareness of accountability mechanisms'. Many have scholars working in social accountability have argued that it is important the people see that change is possible, and they themselves are agents of change $[9,33]$.

The final group of scales were related to collective identity and action, and included: 'Collective efficacy' and 'Community support in the time of crisis'. In collective action, social cohesion and social capital are central to the change process. This starts with groups of people initially identifying commonalities with each other moves towards a belief that the group can work together to bring about changes [11, 30, 31]. Such solidarities provided people with a sense of agency and collective identity necessary to confront unequal power $[12,14,29]$.

The measures also speak to another gap in understanding the poor quality of care still reported in contraceptive services [1, 15, 37]. Harris et al. [15] argue that current tools do not adequately determine the prevalence or impact of negative client experiences in contraceptive programs and that current measures can deemphasise and misdirect attention from client experiences of coercion, corruption, and disrespect and abuse when they come for family planning. The scale, 'Mistreatment by health workers', responds to this gap and by better capturing all dimensions of patients' experience, we can learn what is working, or not, in terms of quality of care [2].

The study benefited from the rigorous methodology for the validation of psychometric scales [6, 27]. A limitation at this stage is that the test-retest was not conducted to examine if the measurement tools reliably replicate the result in the same situation and population. A test-retest was added to the end line data collection.

\section{Conclusion}

In this paper, we share the findings from testing a 58item scale to measure intermediate changes among health service users during a social accountability process to improve contraceptive services. The study suggests that the multi-dimensional scales have high construct validity and reliability in both countries. Though there were differences between contexts and in some of the items and scales, there was convergence in the analysis that suggests that this measure may be relevant to multiple settings and needs to be validated in new settings.

The refined tool resulting from the CaPSAI Project has both research and programmatic utility. It will be useful for research to understand the monitoring and evaluation of social accountability processes and could help develop and target interventions. The validated scales allow for a more robust measurement of the intermediate outcomes. This scale will facilitate measurement to improve community engagement in contraceptive programs.

\section{Abbreviations \\ CaPSAl: Community and Provider Social Accountability Intervention; CFA: Confirmatory Factor Analysis; CFI: Comparative Fit Index; \\ EFA: Exploratory Factor Analysis; KMO: Kaiser-Meyer-Olkin of Sampling Adequacy; MLE: Maximum Likelihood Estimation; NHS: National Health Service; RMSEA: Root Mean Square Error of Approximation; \\ SRMR: Standardized Root Mean Square Residual; WHO: World Health Organization}

\section{Acknowledgments}

The authors are writing this paper on behalf of the CaPSAI Project and would like to acknowledge the CaPSAI Project teams members for their 
significant contribution, specifically: Mary Awelana Addah, Gll; Kamil Fuseini Population Council Ghana; Patrick Kinemo, Sikika; Osei-Bonsu Gyamfi, Gll, Alice Monyo, Sikika; Heather McMullen, Queen Mary's University; Sigilbert Mrema; IHI, Joshua Nkila, Sikika.

Additional conceptual input was provided by James Kiarie (WHO), lan Askew (WHO) and Karen Hardee (Evidence Project) as well as Soe Soe Thin (WHO) for analytical input.

\section{Authors' contributions}

VB: Conceptualization, Methodology, Writing - Original Draft Preparation, Writing - Review \& Editing; PS: Conceptualization, Methodology, Resources, Project Administration, Supervision Writing - Review \& Editing; JPC: Conceptualization, Methodology, Project Administration, Supervision, Writing -Review \& Editing; NH: Formal Analysis, Methodology, Writing -Review \& Editing; MHN: Data Curation, Methodology, Software, Writing - Review \& Editing. DN: Investigation, Methodology, Resources, Writing - Review \& Editing DS: Investigation, Methodology, Resources, Writing - Review \& Editing. The author(s) read and approved the final manuscript.

\section{Funding}

This work was supported by the Bill and Melinda Gates Foundation [OPP1084560] and the United States Agency for International Development (USAID) to the UNDP/UNFPA/UNICEF/WHO/World Bank Special Programme of Research, Development and Research Training Human Reproduction, which is the main instrument and leading research agency within the United Nations system concerned with sexual and reproductive health and rights. reproductive health and rights. This work was supported by the United Kingdom Department for International Development, and the UNDP/UNFPA/ UNICEF/WHO/World Bank Special Programme of Research, Development and Research Training in Human Reproduction (HRP Research).

\section{Availability of data and materials}

The data that support the findings of this study are available from the corresponding author upon reasonable request.

\section{Ethics approval and consent to participate}

CaPSAl Project master and country protocols (Project ID A65896) were approved by technical and ethics review committees at the World Health Organization (WHO). Additionally, the country protocols were reviewed and approved by the Population Council Institutional Review Board (exemption approval- \# EX201714) and Ghana Health Service Ethics Review Committee (GHS-ERC:009/08/2017) in Ghana. In Tanzania, the protocol has been approved by Ifakara Health Institute Institutional Review Board (IH//RB/ No:18-2018 and IHI/RB/AMM/No:03-2019) and the National Institute of Medical Research (NIMR) review board (NIMR/HQ/R.8a/Nol.IX/2668), as well as the NIMR/Mbeya Medical.

Research and Ethics Review Committee (GB.152/377/01/214a).

\section{Consent for publication}

Not applicable.

\section{Competing interests}

No competing interests.

\section{Author details}

1 Global Health Institute, Geneva Graduate Institute, Geneva, Switzerland ${ }^{2}$ UNDP/UNFPA/UNICEF/WHO/World Bank Special Programme of Research, Development and Research Training in Human Reproduction (HRP Research), World Health Organization, Geneva, Switzerland. ${ }^{3}$ Population Council, Accra, Ghana. ${ }^{4}$ Department of Health Systems, Impact Evaluation and Policy, Ifakara Health Institute, Dar es Salaam, Tanzania.

\section{Received: 12 June 2020 Accepted: 23 September 2020}

Published online: 15 October 2020

\section{References}

1. Abdel-Tawab N, RamaRao S. Do improvements in client-provider interaction increase contraceptive con- tinuation? Unraveling the puzzle. Patient Educ Couns. 2010;81(3):381-7.
2. Akachi Y, Kruk M. Quality of care: measuring a neglected driver of improved health. Bull World Health Organ. 2017;95:465-72. https://doi.org/10.2471/ BLT.16.180190.

3. Ali MM, Cleland J, Shah IH. Causes and consequences of contraceptive discontinuation: evidence for 60 demographic and health surveys. Geneva: World Health Organization; 2012.

4. Anthoine E, Moret L, Regnault A, Sbille V, Hardouin J. Sample size used to validate a scale: a review of publications on newly-developed patient reported outcomes measures. Health Qual Life Outcomes. 2014;12:176.

5. Björkman M, Svensson J. Power to the people: evidence from a randomized field experiment of a community-based monitoring project. Q J Econ. 2009; 124(2):735-69.

6. Boateng GO, Neilands TB, Frongillo EA, Melgar-Quiñonez HR, Young SL. Best Practices for Developing and Validating Scales for Health, Social, and Behavioral Research: A Primer. Front Public Health. 2018;6:149. https://doi. org/10.3389/fpubh.2018.00149.

7. Boydell V, Keesbury J. "Social accountability: what are the lessons for improving family planning and reproductive health programs? A review of the literature" working paper. Washington, DC: Population Council, Evidence Project; 2014.

8. Boydell V, Neema S, Wright K, Hardee K. Closing the Gap between People and Programs: Lessons from Implementation of Social Accountability for Family Planning and Reproductive Health in Uganda. Afr J Reprod Health. 2018;22(1):73-84.

9. Dasgupta J. Ten years of negotiating rights around maternal health in Uttar Pradesh. India BMC Int Health Hum Rights. 2011;11:S4.

10. Ewerling E, Victora CG, Raj A, Coll CVN, Hellwig F, Barros AJD. Demand for family planning satisfied with modern methods among sexually active women in low- and middle-income countries: who is lagging behind? Reprod Health. 2018;15:42. https://doi.org/10.1186/s12978-018-0483-x.

11. Galavotti C, Wheeler T, Kuhlmann AS, Saggurti N, Narayanan P, Kiran U. Navigating the swampy lowland: a framework for evaluating the effect of community mobilisation in female sex workers in Avahan, the India AIDS initiative. J Epidemiol Community Health. 2012;66:9-15.

12. George AS. Using accountability to improve reproductive healthcare. Reproductive Health Matters. 2004;11(21):161-70.

13. Gullo S, Galavotti S, Sebert Kuhlmann A, Msiska T, Hastings P, Nathan MC. Effects of a social accountability approach, CARE's Community Score Card, on reproductive health-related outcomes in Malawi: A cluster-randomized controlled evaluation. PlosOne. 2017. https://doi.org/10.1371/journal.pone. 0171316.

14. Hamal M, de Cock BT, De Brouwere V, Bardají A, Dieleman M. How does social accountability contribute to better maternal health outcomes? A qualitative study on perceived changes with government and civil society actors in Gujarat, Indi. BMC Health Serv Res. 2018;18:653.

15. Harris $S$, Reichenbach L, Hardee K. Measuring and monitoring quality of care in family planning: are we ignoring negative experiences? Open Access J Contracept. 2016;7:97-108.

16. Hinkin TR. A review of scale development practices in the study of organizations. J Manag. 1995;21:967-88. https://doi.org/10.1016/01492063(95)90050-0.

17. Jain JK, Obare F, RamaRao S, Askew I. Reducing unmet need by supporting women with met need. Int Perspect Sex Reprod Health. 2013;39(3):133.

18. Joshi A. Legal empowerment and social accountability: complementary strategies toward rights-based development in health? World Dev. 2017;99: 160-72.

19. Kaiser HF. An index of factor simplicity. Psychometrika. 1974;39:31-6.

20. Kaiser HF. The application of electronic computers to factor analysis. Educ Psychol Meas. 1960;20(1):141-51. https://doi.org/10.1177/ 001316446002000116

21. Katchova, A. n.d. "Principal Component Analysis - Econometrics Academy." https://sites.google.com/site/econometricsacademy/econometrics-models/ principal-component-analysis. Accessed 14 Mar 2017.

22. King S. Political capabilities for organization on in Uganda: good governance or popular Organization building? Third World Quart. 2015;36:4 741-757. https://doi.org/10.1080/01436597.2015.1024436.

23. Kline P. Psychological testing. London: Routledge; 2000.

24. Kruk ME, Gage AD, Arsenault C, et al. High-quality health systems in the sustainable development goals era: time for a revolution [published correction appears in lancet glob health. 2018 Sep 18;:] [published 
correction appears in lancet glob health. 2018 Nov;6(11):e1162]. Lancet Glob Health. 2018;6(11):e1196-252. https://doi.org/10.1016/S2214109X(18)30386-3.

25. Longfield K, Montagu D, editors. Quality measurement in family planning: past, present, future: papers from the Bellagio meeting on family planning quality, October 2015. Oakland: Metrics for Management; 2016.

26. Marsh HW, Hau KT, Balla JR, Grayson D. Is more ever too much? The number of indicators per factor in confirmatory factor analysis. Multivar Behav Res. 1998;33(2):181-220.

27. Morof D, Steinauer J, Haider S, Liu S, Darney P, Barrett G. Evaluation of the London Measure of Unplanned Pregnancy in the a United States population of women. PloS One. 2012;7:4.

28. NHS. Shared decision making: summary guide. 2019. https:/www.england. nhs.uk/wp-content/uploads/2019/01/shared-decision-making-summaryguide.pdf. Accessed 08 Aug 2018.

29. Papp SA, Gogoi A, Campbell C. Improving maternal health through social accountability: a case study from Orissa. India Glob Public Health. 2013;8: 449-64

30. Saggurti N, Atmavilas Y, Porwal A, Schooley J, Das R, Kande N, Irani L, Hay K. Effect of health intervention integration within women's self- help groups on collectivization and healthy practices around reproductive, maternal, neonatal and child health in rural India. PLoS One. 2018;13(8):e0202562. https://doi.org/10.1371/journal.pone.0202562.

31. Saggurti N, Mishra RM, Proddutoor L, Tucker S, Kovvali D, Parimi P, Wheeler T. Community collectivization and its association with consistent condom use and STI treatment-seeking behaviors among female sex workers and high-risk men who have sex with men/transgenders in Andhra Pradesh, India. AIDS Care. 2013;25:55-66. https://doi.org/10.1080/09540121.2012. 749334 PMID: 23745631

32. Schreiber JB, Nora A, Stage FK, Barlow EA, King J. Reporting structural equation modeling and confirmatory factor analysis results: a review. J Educ Res. 2006;99:6, 323-338. https://doi.org/10.3200/JOER.99.6.323-338.

33. Scott K, George AS, Harvey SA, Mondal S, Patel G, Gilson L, Sheikh K Negotiating power relations, gender equality, and collective agency: are village health committees' transformative social spaces in northern India? Int J Equity Health. 2017;16(1). https://doi.org/10.1186/s12939-017-0580-4.

34. Sebert Kuhlmann AK, Gullo S, Galavotti C, Grant C, Cavatore M, Posnock S. Women's and health workers' Voices in open, inclusive communities and effective spaces (VOICES): measuring governance outcomes in reproductive and maternal health Programmes. Dev Policy Rev. 2017;35(2):289-311.

35. Singh $\mathrm{S}$, et al. Adding it up: the costs and Benefi ts of investing in family planning and maternal and newborn health. New York: Guttmacher Institute and United Nations Population Fund; 2017.

36. Steyn PS, Boydell V, Cordero JP, et al. Rationale and design of a complex intervention measuring the impact and processes of social accountability applied to contraceptive programming: CaPSAI project [version 1; peer review: 1 approved]. Gates Open Res. 2020;4:26. https://doi.org/10.12688/ gatesopenres.13075.1.

37. Tumlinson K. Measuring quality of care: a review of previously used methodologies and indicators, Working Paper Two of the Measuring and Monitoring Quality of Services and Quality of Care Project. New York: Population Council; 2016.

38. Wegs C, Creanga AA, Galavotti C, Wamalwa E. Community Dialogue to Shift Social Norms and Enable Family Planning: An Evaluation of the Family Planning Results Initiative in Kenya. Plos One. 2016. https://doi.org/10.1371/ journal.pone.0153907.

39. WHO. Closing the gap in a generation: Health equity through action on the social determinants of health. Geneva: WHO; 2008.

40. WHO. Declaration of Astana: global confernce on primary health care Geneva: WHO; 2018.

41. Williams G. Evaluating participatory development: tyranny, power and (re)politicization. Third World Q. 2004;25(3):557-78.

42. Wright $\mathrm{KQ}$, Boydell V, Hardee K. Validating a measure of rights-based family planning service delivery. Chicago: Presented at the 2017 annual Population Association of America Meeting in the session "Fertility, Family Planning and Sexual Health: Programs and Policies; 2017.

\section{Publisher's Note}

Springer Nature remains neutral with regard to jurisdictional claims in published maps and institutional affiliations.

Ready to submit your research? Choose BMC and benefit from:

- fast, convenient online submission

- thorough peer review by experienced researchers in your field

- rapid publication on acceptance

- support for research data, including large and complex data types

- gold Open Access which fosters wider collaboration and increased citations

- maximum visibility for your research: over $100 \mathrm{M}$ website views per year

At $\mathrm{BMC}$, research is always in progress.

Learn more biomedcentral.com/submissions 